\title{
DISABILITIES AND THE CANADIAN FORCES MEDICAL SYSTEM
}

\section{STANLEY J. BLYTHE*}

This article examines and challenges some of the assumptions, procedures and standards implicit in the Canadian Forces (CF) treatment of the disabled. From a human rights perspective, the $C F$ classification system can exclude an individual from joining the $C F$ or may result in the release of a serving member from the CF. The author develops this article in the context of evolving Canadian human rights law and its inherent conflict with the traditional role of the $C F$. The author views the $C F$ 's primary role as being prepared for combat with the forces of a national enemy. At the root of this article is whether CF members are to be considered "soldiers first" or are to fit within the current legal standards and societal norms recognizing disabled persons' rights in the workforce.

The author reaches the conclusion that the CF is unique among Canada's employers. While not called upon very often, the primary role of the $C F$ is to provide an armed force for Canadian defence. Although there should be appropriate variations for the responsibilities of individuals in peacetime and wartime periods, a high standard of medical fitness is justified for Canadian service members. Finally, despite the fact that many military decisions regarding the disabled have been upheld in our courts, the author proposes several reforms to enhance the military's sensitivity to its disabled recruits and serving members.
Le présent article examine et remet en question certains des postulats, procédures et normes implicites dans le traitement des Forces canadiennes envers les personnes handicapées. Dans la perspective des droits de la personne, le système de classification des FC peut empêcher certaines personnes de se joindre aux $F C$ ou provoquer la mise à pied des militaires actifs. $L$ 'auteur aborde la question dans le contexte de l'évolution des droits de la personne et du conflit inhérent que pose le rôle traditionnel des FC - qui consiste, comme il le souligne, à combattre la force armée d'un pays ennemi. L'auteur se demande si les militaires des FC sont avant tout soldats ou si les FC doivent se conformer aux normes juridiques et sociales qui reconnaissent l'égalité des chances des personnes handicapées sur le marché du travail.

$L$ 'auteur conclut que les FC occupent un rang unique parmi les employeurs du Canada. Bien qu'il ne soit pas mis en oeuvre très souvent, le rôle des CF consiste avant tout $\grave{a}$ assurer la défense nationale. Bien que les responsabilités puissent varier en temps de guerre et en temps de paix, il convient d'exiger une condition physique de haut niveau des militaires actifs. Finalement, bien qu'un grand nombre de décisions militaires relatives aux personnes handicapées aient été confirmées, l'auteur propose plusieurs réformes visant d̀ promouvoir la sensibilité des FC envers les recrues et les militaires actifs handicapés.

\section{TABLE OF CONTENTS}

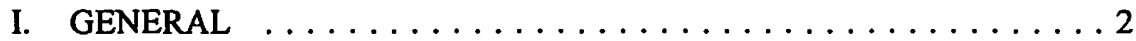

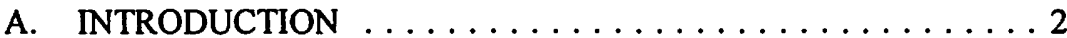
B. OVERVIEW OF THE SYSTEM $\ldots \ldots \ldots \ldots \ldots \ldots \ldots$
C. GENERAL, ENVIRONMENTAL, AND MILITARY OCCUPATION SPECIFICATIONS $\ldots \ldots \ldots \ldots \ldots \ldots$
D. CAREER MEDICAL REVIEW BOARD .......... 13

\footnotetext{
Commander, Judge Advocate General's Office; Director of Law/Human Rights and Information, Canadian Forces. This paper was prepared in partial completion of an LL.M. at the University of Ottawa, Ottawa, Ontario, April 1994. The views expressed in this article are those of the author and do not necessarily reflect the opinion or policy of the Office of the Judge Advocate General, the Canadian Forces, the Department of National Defence, or the Government of Canada.
} 


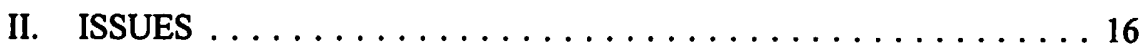

A. DISCRIMINATION: THE BFOR AND

REASONABLE ACCOMMODATION DEFENCES ...... 16

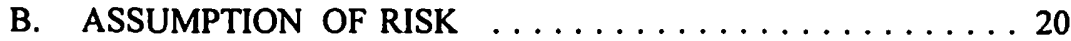

C. THE ENVIRONMENTAL SPECIFICATIONS $\ldots \ldots \ldots \ldots 22$

D. UNIVERSALITY OF SERVICE -

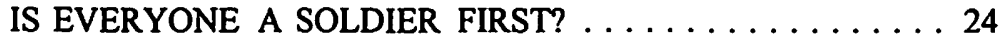

E. NON-COMMISSIONED MEMBER (NCM)

VERSUS OFFICER RELEASE RATES $\ldots \ldots \ldots \ldots \ldots 32$

F. SAME STANDARD FOR ALL RANKS

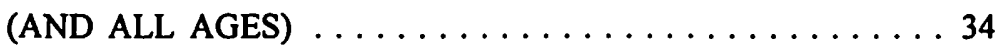

G. TREATING EXISTING EMPLOYEES

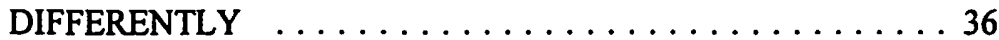

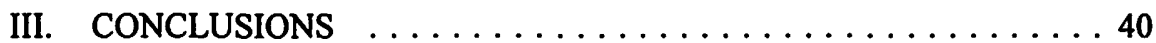

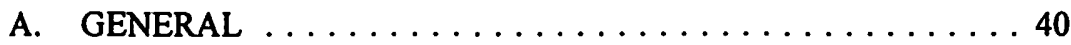

B. THE CANADIAN FORCES MEDICAL SYSTEM ...... 42

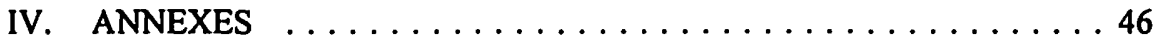

And therefore though the sword be put into the Sheath, we must not suffer it there to rust or stick so fast, as that we shall not be able to draw it readily when need requires. For albeit our enemies have of late years sought peace with us, yet hath it proceeded out of the former tryall of our forces in times of war and Enmity.

Sir Walter Raleigh,

Observations on the Navy and Sea Service.

\section{GENERAL}

\section{A. INTRODUCTION}

With these words, Sir Walter Raleigh reminds us that, though we are presently at peace and the superpowers have put away their enmity, this peace can be seen as a direct result of past conflict, confrontation and deterrence. Moreover, even in this climate, with its emphasis on the peace dividend and an enhanced role for the United Nations, there still exist a variety of regional conflicts, some of which affect Canadian interests and some of which Canada may choose to attempt to resolve through peacekeeping forces.

The Canadian Forces (CF) have historically demanded a high standard of physical and mental fitness of all soldiers, sailors and air force personnel. This makes obvious sense when the nation is sending its forces overseas to engage in deadly combat with the forces of a national enemy. In such circumstances, a high standard of fitness is advantageous to the survival of the individual, the safety of other soldiers who depend on his or her performance, and the achievement of the national objective, which may be the pacification of a local conflict, the simple deterrence of aggression, or national survival itself. But this simple logic is much less obvious in a time of prolonged peace, in a time when Canada has no obvious enemies, and when the very roles of the CF are under reevaluation. In addition, the increasing specialization and sophistication of 
military forces have led to an increase in the number of members of the CF whose primary work is more related to specialties such as administration, logistics, finance, medicine, and so on. We must examine the argument that these service members are "soldiers first", and so must be fit to defend themselves and contribute to the defence effort in a military way.

This article will focus on that part of the CF medical system which concerns policies toward the disabled as recruit applicants and as serving members. CF personnel policies will be analyzed, particularly as they affect employment decisions and are governed by human rights policy and law.

The article will examine the system and rationale by which the CF translates its roles into Military Occupations, then into Specifications, and then into medical standards. The importance of these medical standards, from a human rights perspective, lies in the fact that an individual who does not meet them may either be excluded from joining the $\mathrm{CF}$ as a recruit, or may be released from the CF if some medical condition causes the serving member to fall below the standard. This is a system of planned discrimination on the basis of disability. Under the Canadian Human Rights Act, ${ }^{1}$ it will only be defensible if the medical requirement is a Bona Fide Occupational Requirement (BFOR) or if no reasonable accommodation ${ }^{2}$ is feasible. This article will describe the medical factors that underlie the $C F$ medical standards and will examine the rationale for the three types of career or training Specifications. ${ }^{3}$ The purpose will be to examine and challenge some of the assumptions, procedures, and standards implicit in the way the CF medical system treats the disabled.

\section{B. OVERVIEW OF THE SYSTEM}

The CF achieves its multitude of complex roles ${ }^{4}$ by specializing its personnel, while at the same time attempting to retain as much flexibility and depth or "bench strength" in its organization as possible by cross-training, rotating through various jobs and locations, and demanding that all of its personnel remain ready to perform a certain core of "universal" tasks such as personal self-defence. The pilot who flies high performance combat jets and the soldier who maintains logistic support to front line army units will each require distinct specialized training and skills, but they will both

R.S.C. 1985 , c. H-6.

2 The "reasonable accommodation" requirement is a judge-made evolution that will be discussed below.

3 The three Specifications are: the General Specification that applies to every CF member, the Military Occupation Specification that describes the requirements of a given military occupation, and the Environmental Specification that describes the requirements of the working environment: Land, Sea, or Air. These will be described more fully below.

Generally described as: (a) strategic deterrence, (b) conventional defence, (c) protection of Canadian sovereignty, (d) peacekeeping, and (e) arms control. See the 1987 White Paper on Defence, Challenge and Commitment - A Defence Policy for Canada (Ottawa: Canadian Government Publishing Centre, 1987), and a subsequent policy statement by the Minister of National Defence at the National Press Theatre on September 17, 1991 (and comment in The [Toronto] Globe and Mail (18 September 1991) A1, A6). 
be responsible to maintain a certain level of physical fitness and an ability to use small firearms appropriate for self-defence in a battle area.

The CF is divided into three components: the Regular Force, the Reserve Force and, when established, the Special Force. ${ }^{5}$ Although medical and career administrative practices differ between the Regular and Reserve forces, this is largely as a result of practical differences in support and staffing, rather than more fundamental or philosophical differences. The Department of National Defence and the CF have, at least since 1987, emphasized the integration of the Reserve and Regular Forces into a "Total Force" with uniform policies and procedures. In at least two instances, human rights tribunals have declined to differentiate between the two in deciding a case. ${ }^{6}$ For these reasons, this study of the CF Medical System will not attempt to draw any distinctions between the Regular Force and Reserve Force.

The military occupation structure is first divided into commissioned and noncommissioned ranks and then into various military occupations. There are 37 officer military occupations ranging from pilot, to maritime surface and sub-surface officer, to legal officer. There are 102 non-commissioned military occupations such as infantryman, naval signalman and administrative clerk. ${ }^{?}$

The occupational structure is used to provide a means of identifying the personnel skills and knowledge necessary to perform the jobs which must be done by the CF. This occupational structure must pursue two conflicting goals: it must attempt to maximize the efficiencies of specialization, but at the same time it must retain the flexibility that goes with broad training and redundant capabilities. While pure efficiency might be the dominant goal in a well-defined and stable civilian manufacturing task, flexibility must be maintained in a military environment, where goals and tasks can only be defined in general terms until the crisis arrives and when the very nature of the tasks assume that many valuable people are likely to be lost as casualties.

To provide some consistency in the knowledge and skills required of its personnel, the CF has created a system of "Specifications" which describe the tasks, knowledge level and skill level required of personnel in various situations. Every person is subject to three Specifications, one related to their military occupation, one related to their environment (i.e. sea, land or air) and a General Specification which applies to all officers and non-commissioned members in the CF. The aim is that the Specifications will provide an objective basis for training and assessing members of the CF. These Specifications will be discussed further in the next section. 
Another role of these Specifications is to provide an objective basis for the physical and medical requirements of recruits and members of the CF. All potential and serving members are assessed and categorized under six medical factors:
V -visual acuity
CV -colour vision
$\mathrm{H}$-hearing
G -geographical limitation
O -occupational limitation
A -aircrew standards

A visual acuity of "V1" is the highest standard and is the level required for a pilot. It requires uncorrected vision of "6/6" in the better eye and "6/9" in the other eye. ${ }^{8}$ By way of contrast, the minimum standard required for some of the military occupations is "V4" which corresponds to corrected vision of "6/9" in the better eye and "6/120" in the other eye. The category "V6" is assigned to recruit candidates with worse than "V4" vision; they are precluded from joining the CF."

Colour vision is similarly assigned a grading from 1 to 3 . Only one military occupation, ammunition technician, requires "normal" or CV1. CV3 or poor colour vision is acceptable for many of the support trades. ${ }^{10}$

The ability to hear the spoken voice and auditory signals, often against considerable background noise, is considered paramount for some trades. " Hearing is assigned a grade from 1 to 5 . For example, $\mathrm{Hl}$ means a maximum hearing loss of 30 decibels (dbs) in both ears in the 500 to 6,000 frequency range. H4 means a maximum hearing loss of $50 \mathrm{dbs}$ in the 500 to 2,000 frequency range. Notably, if hearing can be improved to an $\mathrm{H} 4$ level or better with a hearing aid, an $\mathrm{H} 4$ level is assigned. ${ }^{12}$

The most controversial and contested medical factors are the Geographical and Occupational factors. The Geographical factor is an attempt to describe where an individual is expected to be able to perform efficiently, taking into account three main factors: climate, accommodation (and living conditions), and available medical care. Climate may be important because, for example, a skin disease may be aggravated by either hot moist or cold dry climates, and certain peripheral vascular diseases, by the

Medical Standards for the CF, A-MD-154-000/FP-000, Annex A [hereinafter Medical Standards]. The numbers "6/9" signify that when the individual stands 6 metres from a standard eye chart, s/he is able to read line number 9 on the chart. The line number corresponds to the distance at which a person with normal vision could read the line, also in metres. See Appendix 1 to Annex A (of the above-noted publication) for further description of the test conditions.

- This minimum entry level for vision was upheld in Husband v. Canadian Armed Forces (14 April 1994), A-799-91 (F.C.A.) [unreported]. See further discussion below, text accompanying notes 73 and 92.

10 Medical Standards, supra note 8 at 2-2 and Annex D.

"T Twenty-seven military occupations require a hearing standard of $\mathrm{H} 2$ (see Annex A). Examples are pilot, maritime engineer, flight engineer, and airbome electronic sensor operator. 
cold. Some trades and tasks will quite predictably require the individual to live out in the open in inclement weather for extended periods, and on minimal rations. This is likely to be beyond the capabilities of individuals with some medical limitations. Military training and missions often involve isolation and combat (or simulated combat) conditions. With both isolation and combat conditions, it becomes predictable that medical conditions will become less than ideal and that evacuation will become more difficult. This will preclude persons with some limitations from undertaking some tasks. The Geographical factor is graded from 1 to 6 as follows:

G1 - No limitations - The individual's health allows him or her to be fully employed anywhere in the world with minimal risk of becoming ineffective as a result of climate, living conditions, or the unavailability of even minimal medical care.

G2 - The individual has a minor medical condition, not requiring regular medical support, and which does not preclude employment in any climatic or environmental condition.

G3 - The individual requires medical care (not necessarily a physician's) about every three months. The individual is still considered fit for operating in the field, at sea and in isolated locations. ${ }^{13}$

G4 - Climatic or Isolation Limitation 14 - The individual requires "barrack", as opposed to field or sea, accommodation, as well as readily available physicians' services. The individual is unfit for a medically isolated posting because of either a serious medical disability or a milder disability with the potential for sudden serious complications.

G5 - Restriction to Canada (urban environments) - The individual requires "barrack" or equivalent accommodation, as well as medical specialist care. A medical disability requires or is likely to require periodic medical care, but the individual can perform essential work most of the time in a modern urban environment.

G6 - Medically unfit for military service. A disease or disability is geographically incompatible with the stress and requirements of military life. ${ }^{15}$ cannot be assigned to a single climatic environment or sent to sea. recruit with a problem of recurrent dislocation of the knees, see: Boivin v. Canadian Armed Forces (25 January 1994), TD 2/94 (C.H.R.T.) [unreported] [hereinafter Boivin]. 
These gradations can be summarized by the following table.

\begin{tabular}{|c|c|c|c|c|c|}
\hline \multicolumn{6}{|c|}{ Geographical Factor ${ }^{16}$} \\
\hline & Climatic & & Environmental & & $\begin{array}{l}\text { Medical } \\
\text { (frequency, skill, } \\
+ \text { support level) }\end{array}$ \\
\hline G1 & no limitations & and & no limitations & and & $\begin{array}{l}\text { nil, buddy, first } \\
\text { aid kit }\end{array}$ \\
\hline G2 & $\begin{array}{l}\text { no limitations (or } \\
\text { single restriction } \\
\text { re equatorial } \\
\text { environment) }\end{array}$ & and & $\begin{array}{l}\text { no limitations (or } \\
\text { single restriction } \\
\text { re maritime } \\
\text { environment) }\end{array}$ & and & $\begin{array}{l}\text { occasional, } \\
\text { ancillary, Med. } \\
\text { Asst. pouch, over } \\
\text { the counter drugs. }\end{array}$ \\
\hline G3 & $\begin{array}{l}\text { no limitations (or } \\
\text { single restriction } \\
\text { re equatorial } \\
\text { environment) }\end{array}$ & and & $\begin{array}{l}\text { no limitations (or } \\
\text { single restriction } \\
\text { re maritime } \\
\text { environment) }\end{array}$ & and & $\begin{array}{l}\text { periodic, ancillary, } \\
\text { destroyer med. } \\
\text { support/ Unit } \\
\text { Medical Spt. } \\
\text { pannier (i.e. } \\
\text { integral medical } \\
\text { support) }\end{array}$ \\
\hline G4 & $\begin{array}{l}\text { arctic or arctic }+ \\
\text { tropical limit }\end{array}$ & $\begin{array}{l}\text { and/ } \\
\text { or }\end{array}$ & $\begin{array}{l}\text { barracks or } \\
\text { equivalent } \\
\text { conditions }\end{array}$ & $\begin{array}{l}\text { and/ } \\
\text { or }\end{array}$ & $\begin{array}{l}\text { sustained, } \\
\text { physician, Base } \\
\text { medical facility }\end{array}$ \\
\hline G5 & $\begin{array}{l}\text { arctic or arctic }+ \\
\text { tropical limit }\end{array}$ & $\begin{array}{l}\text { and/ } \\
\text { or }\end{array}$ & $\begin{array}{l}\text { barracks or } \\
\text { equivalent - } \\
\text { restricted to } \\
\text { Canada }\end{array}$ & $\begin{array}{l}\text { and/ } \\
\text { or }\end{array}$ & $\begin{array}{l}\text { sustained, } \\
\text { specialist, military } \\
\text { hospital }\end{array}$ \\
\hline G6 & severe limitations & or & $\begin{array}{l}\text { maximal } \\
\text { limitations }\end{array}$ & and & $\begin{array}{l}\text { beyond capability } \\
\text { of } C F\end{array}$ \\
\hline
\end{tabular}

The Occupational factor is an assessment of how an individual will be able to cope with the physical and mental activities and stresses related to an occupation. It is graded from 1 to 6 as follows:

O1 - Above average fitness - Free from mental and physical disabilities and trained to endure sustained hard muscular work at a rapid rate under severe stress. Such an individual would possess unusual strength and stamina and would excel at front-line combat. 
O2 - No limitations - Free from medical disabilities apart from minor limitations which would not impair the ability to perform with acceptable endurance in frontline combat or heavy physical work.

O3 - Moderate medical disability ${ }^{17}$ - Able to perform most tasks in moderation, but prevented by moderate medical disability from performing heavy physical work or operating under stress for sustained periods.

O4 - Light Duties - A mental disability preventing an individual from coping with severe or prolonged stress (i.e. restricting him or her to routine administrative duties), or a physical disability restricting the individual to light duties.

O5 - Sedentary Duties - Although severely restricted, an individual can perform useful sedentary work if $\mathrm{s} / \mathrm{he}$ can set his/her own pace. (Retention in the Forces is contingent on finding the right job in the right place for a well-trained skillful person.)

O6 - Medically Unfit for Military Service - The individual has a disability which is incompatible with the demands and stresses of military life..$^{18}$

Occupational Factor ${ }^{19}$

\begin{tabular}{|c|c|c|c|c|c|c|c|}
\hline \multicolumn{4}{|c|}{ Physical Stress } & \multicolumn{4}{|c|}{ Mental Stress } \\
\hline & Duration & & Intensity & & Duration & & Intensity \\
\hline 01 & $\begin{array}{l}\text { extraordinary, } \\
\text { sustained pds. > } \\
24 \text { hrs. }\end{array}$ & and & $\begin{array}{l}\text { severely } \\
\text { physically } \\
\text { demanding }\end{array}$ & and & $\begin{array}{l}\text { extraordinary, } \\
\text { sustained } \\
\text { periods }\end{array}$ & and & $\begin{array}{l}\text { extraordinarily } \\
\text { severe }\end{array}$ \\
\hline $\mathrm{O} 2$ & $\begin{array}{l}\text { expected } \\
\text { sustained pds. } \\
\sim 24 \text { hrs. }\end{array}$ & and & $\begin{array}{l}\text { physically } \\
\text { demanding }\end{array}$ & and & $\begin{array}{l}\text { expected } \\
\text { sustained pds. }\end{array}$ & and & severe \\
\hline $\mathrm{O} 3$ & $\begin{array}{l}\text { limited pds. } \\
-8-12 \text { hrs. }\end{array}$ & $\begin{array}{l}\text { and } \\
\text { lor }\end{array}$ & $\begin{array}{l}\text { moderately } \\
\text { physically } \\
\text { demanding }\end{array}$ & $\begin{array}{l}\text { and } \\
\text { lor }\end{array}$ & limited pds. & $\begin{array}{l}\text { and } \\
\text { lor }\end{array}$ & $\begin{array}{l}\text { moderately } \\
\text { severe }\end{array}$ \\
\hline 04 & $\begin{array}{l}\text { defined limited } \\
\text { pds. }<8 \mathrm{hrs} \text {. }\end{array}$ & $\begin{array}{l}\text { and } \\
\text { for }\end{array}$ & light & $\begin{array}{l}\text { and } \\
\text { lor }\end{array}$ & $\begin{array}{l}\text { defined limited } \\
\text { pds. }\end{array}$ & $\begin{array}{l}\text { and } \\
\text { lor }\end{array}$ & moderate \\
\hline
\end{tabular}

The distinction between $\mathrm{O} 2$ and $\mathrm{O} 3$ was applied in the case of a recurring dislocation of the knees in Boivin, supra note 14.

18 Medical Standards, supra note 8 at 2-4 to 2-5.

$19 \quad$ Supra note 16. 


\begin{tabular}{|l|l|l|l|l|l|l|l||}
\hline \hline \multicolumn{3}{|c|}{ Physical Stress } & \multicolumn{4}{c||}{ Mental Stress } \\
\hline & Duration & & Intensity & & Duration & & Intensity \\
\hline O5 & own pace & $\begin{array}{l}\text { and } \\
\text { lor }\end{array}$ & sedentary & $\begin{array}{l}\text { and } \\
\text { /or }\end{array}$ & own pace & $\begin{array}{l}\text { and } \\
\text { /or }\end{array}$ & light \\
\hline O6 & \multicolumn{1}{|l||}{} \\
\hline
\end{tabular}

Finally, the Air factor rates an individual's capacity to act as a pilot, aircrew or passenger in various circumstances. This factor has given rise to no litigation that $I$ could find, perhaps because of the generally accepted importance of a pilot's physical and mental state, and similar parallels in the regulation of civilian pilots.

Note that although the Geographical and Occupational categories, particularly G5 and O5, drop to a remarkably low level of fitness before an individual is considered unfit for military service, this is deceptive for two reasons. First, there is a Common Minimum Enrolment Standard (CMES), which potential recruits must meet to be eligible to join the CF. It is: V4 - CV3 - H2 - G2 - O2 - A5, ${ }^{20}$ which is higher than the minimum standards for some military occupations. This distinction in standards between potential and serving members will be discussed below. Second, the minimum medical standards for each military occupation do not drop below G3 and O3. The possibility of remaining in the Forces with lower assessments than these will depend on a waiver of these requirements which in itself depends on matching the right skills with the right job. This raises interesting questions which will be discussed below.

\section{GENERAL, ENVIRONMENTAL, AND MILITARY OCCUPATION SPECIFICATIONS}

The Military Occupation Specifications were described above as lists of tasks, knowledge levels, and skills required of personnel in various situations. They are intended to provide an objective basis to hire, train, employ, and assess personnel. Their importance, from a human rights perspective, is that they form the basis of the medical and physical requirements which are quantified under the six medical factors and are then used to assess the suitability of job applicants and the continuing suitability of existing members.

As might be expected, Military Occupation Specifications are the subject of the least number of human rights complaints because they are the most specific and, after all, an employer has every motivation to describe its jobs accurately. It would be counterproductive to include requirements which are extraneous to the job, as this would impose unnecessary training requirements and might eliminate otherwise qualified 
applicants. It is possible that objection may be made to the boundaries chosen between occupations, for instance in dividing communications trades along the lines of naval signalmen, naval radio operators, and land-based equivalents. However, one would expect few complaints and, in general, the employer would enjoy wide leeway in structuring its occupations and job descriptions to achieve efficiency in its training and promotion as well as in choosing occupational divisions that will best match equipment maintenance plans. ${ }^{21}$

Individual human rights complaints may hinge on the Military Occupation Specification, but these should be resolvable with objective evidence about the requirements of the job. For example, in Rivard v. Department of National Defence, ${ }^{22}$ a knee injury prevented a tank crewman from continuing in that trade. He wanted to transfer to the less active trade of administrative clerk but a medical restriction (that he not stand for prolonged periods) conflicted with the requirement that an administrative clerk stand for long periods at the counter to provide services. However, one issue that will have to be answered is whether such a Military Occupation Specification should be demanded of all persons in a given trade. Again, we find the CF trying to distinguish itself from other employers by requiring that its personnel be interchangeable and relocate regularly. This issue is addressed more directly under the General Specifications for all CF personnel which will be discussed below.

The Environmental Specifications apply only to personnel posted within a given environment. ${ }^{23}$ Given the tendency, since integration in 1968, to post people between environments, ${ }^{24}$ an individual will have to meet differing standards depending on where the current job places him or her. The Land Field Force Environmental Qualification ${ }^{25}$ demands skill in performing under field conditions such tasks as firing and maintaining various weapons: rifle, sub-machine gun, light machine gun, anti-tank weapons, grenades, pistol, and anti-personal and anti-tank mines. Personnel must be competent in radio communication, camouflage and concealment, and cross country movement, and be able to finish a ten mile march carrying certain combat equipment in two hours and forty-five minutes on two consecutive days. The Sea (surface) Environmental Qualification demands skill in a variety of naval tasks such as ship board fire fighting, radiation detection, damage control, and boat handling. ${ }^{26}$ These tasks seem unobjectionable for personnel training for combat in these environments, but it must be remembered that all personnel in the field and in ships must be competent in these areas. This will include the cooks and administrative clerks in the ships, as well as the finance clerks and supply technicians in the field. The former serve with their ships at sea and so must be prepared to cope with any seagoing emergencies, including

For example, the split between Naval Radio Operator and Naval Electronic Technician (Communications), see Trade numbers 274 and 284 respectively, at Annex A.

(1990), 12 C.H.R.R. D/35 (Fed.) [hereinafter Rivard].

The three CF environments are Land, Sea, and Air.

For example, a service member may be transferred from an army unit or Base (in the Land environment) to a naval ship (the Sea environment).

Canadian Forces Manual of Non-Commissioned Member's Occupation Structure, A-PD-123004/PQ-011.

Ibid. 
explosions, fires, and noxious fumes. The latter, although members of support trades, are integrated into their battalion or regiment and must be prepared to defend themselves and carry out combat-oriented missions.

Distinctions between the CF and most other employers are most evident where job requirements arise from a "General" military duty, as opposed to a specific job. These requirements may be performed infrequently or may be performed only if Canada goes to war. As an example, an administrative clerk who is posted to a military base will generally perform a fairly clerical function and yet is subject to such duties as Base Defence Force, which can involve the use of firearms and front-line confrontation with rioters, saboteurs or terrorists. In the event of war such a clerk may well be required to perform duties with his/her unit in a battle zone, bearing full responsibility for self defence and survival. Even in peace-time, an administrative clerk's duties may have to be performed in a remote and isolated location where medical and other support services are rudimentary and evacuation is difficult. Although some job requirements may only be needed in the event of national emergency, war, or crisis, it must be remembered that response to those events is the primary purpose for the training, and even the existence, of the CF. Unlikely though some of these events may be, the response would be critical.

The General Specifications (one for officers and one for other ranks) are an attempt to list those essential tasks and skills which are common to every person in the military. They have also been called "the basic duties expected of all service personnel regardless of occupation. ${ }^{127}$ The officer General Specification ${ }^{28}$ requires every officer to:

a) accommodate mental stress from "normal to extremely high"; under some circumstances "hazards will involve disability or death";

b) maintain a level of physical fitness which will enable them to meet the physical demands of their normal duties and have sufficient reserve to meet any emergency;

c) attain and maintain the Basic Military Swimming Level;

d) be capable of rendering emergency first aid including cardiopulmonary resuscitation;

e) be skilled in performing foot drill movements with and without arms;

f) be skilled in the operation and safe handling of the service pistol, service rifle and sub-machine gun; 
g) be capable of eating, drinking, firing service pistol, and performing their primary duty while dressed in the full chemical warfare suit; and

h) be semi-skilled in fire fighting. ${ }^{29}$

While these task and skill descriptions provide a general idea of the areas in which training should be undertaken, they are very vague in terms of the physical and mental capabilities required. Even though such terms as "Basic Military Swimming Level", "skilled", and "semi-skilled" are defined in appropriate contexts elsewhere, there is a basic problem in being objective and consistent in assessing an individual's ability to accommodate "extremely high" stress or in knowing what physical reserves will be necessary to "meet any emergency." The General Specifications for officers are very vague and so one can anticipate difficulty in translating them into neat medical factors and categories. Then too, there is the question of whether every single officer must really have these somewhat exceptional physical and mental capabilities. Should they instead be held only to a standard sufficient to meet their primary duties, plus a range of contingencies which they may potentially or even probably meet during their careers? Should the standard change depending on the rank of the individual? With increasing seniority in rank, an individual will assume a more supervisory position, which will be more removed from the front-line or the "cutting edge" of the crisis. For example, the Commanding Officer of a ship or battalion is less likely to be required to use a fire hose in an emergency than one of the more junior officers or noncommissioned members, although his or her response could be critical in reacting to a fire in given circumstances. To what extent should these probabilities govern the training and minimum medical requirements of senior personnel?

The General Specification for non-commissioned members $(\mathrm{GSNCM})^{30}$ is considerably longer and more detailed than that for officers. It has similar statements concerning physical demands, family relocation, isolation, stress and the possibility of disability and death. It also provides detail on numerous common tasks and the skill level required for each rank. For example, all Privates and Corporals must be able to fire and maintain a rifle under minimal supervision. Master Corporals and higher ranks must, in addition, be able to supervise these tasks. Privates must also have some ability to use and maintain the sub-machine gun. ${ }^{31}$ Note that these skills apply to every Private in the CF, from infanteers to administrative clerks and musicians. Similarly, every NCM must maintain a level of physical fitness and ability to swim as described in administrative orders, navigate on the ground by day and night using a chart and compass, and participate in internal security and Base Defence Force operations. ${ }^{32}$

Although the GSNCM is considerably more detailed than that of the officers, it still raises some interesting questions. Do these standards really have to be met by

Ibid. at 2-2-2 to 2-3-19.

Canadian Forces Non-Commissioned Member Trade Structure, A-PD-123-001/AG-001, c. 3, Annex A [hereinafter NCM Trade Structure].

Ibid. at 3A-13.

Ibid. at $3 \mathrm{~A}-15$ to 16 . 
everyone? Do the minimum enrolment standards fairly reflect these Specifications? For example why is a certain level of "uncorrected" vision needed for these activities? Given the normal tendency for more senior personnel to hold supervisory positions, is it really necessary for all rank levels to meet the same physical standards? These questions will be addressed below.

To summarize then: an analysis of the roles of the CF leads to the definition of some 139 military occupations within which members of the CF will be trained and assessed. The tasks, knowledge and skills required for these occupations are described in detailed Military Occupation Specifications. In addition, the skills and abilities required for all members of the CF and for each working environment (sea, land, and air) are described in the General and Environmental Specifications respectively. These Specifications are then subjected to medical scrutiny and a determination is made as to the minimum medical categories which will be acceptable for members of each military occupation, ${ }^{33}$ and for all potential recruits into the $C F{ }^{34}$ Provision is made for exceptions both for recruits, when they possess special skills, experience, or professional qualifications, and for experienced service members, whose medical categories fall below the minimum for their trades. Both of these exceptions will be examined in greater detail below.

\section{CAREER MEDICAL REVIEW BOARD}

When the physical or mental condition of a serving member of the CF changes, it may result in a change in medical category. Such a change may be temporary and treatable. The first priority is to treat the condition and return the member to full active duty if possible. A military doctor may impose a temporary limitation on the type of employment the member can perform, so that the problem will not be aggravated. In the case of a permanent reduction in medical category, it may fall below the minimum specified for the member's military occupation or may preclude employment in the present job, environment (land, sea, or air), or geographic location. This in turn may indicate a need to change occupation or even a release from the CF. In an effort to ensure these decisions are made fairly and consistently across the Forces, these decisions are referred to a Career Medical Review Board (CMRB) in Ottawa. ${ }^{35}$

The CMRB is made up of five representatives from the personnel management section, the career management section, and the Surgeon General's section. The CMRB can recommend ${ }^{36}$ one of four options:

a) continued employment in present capacity with career limitations (such as limits on employment or promotion),

34 That is, the Common Minimum Enrollment Standard (CMES): V4 - CV3 - H2 - G2 - O2 - A5.

35 Canadian Forces Administrative Order 34-26.

36 The recommendation is passed for approval to a higher authority. The authority to approve varies depending on the rank of the member in question. 
b) continued employment in present capacity without career limitations,

c) transfer to another trade or posting to another job, or

d) release from the $\mathrm{CF}$.

During the CMRB's review, the medical officer provides a description of the employment limitations caused by the member's medical condition. The CMRB attempts to review every factor relevant to further employability including: the medical prognosis, time remaining until compulsory retirement or end of present engagement, rank held, promotion potential, suitability for employment in other trades, duration of training required to achieve journeyman status in the new trade, requirement for continual and immediate medical treatment services, and pension implications of release. $^{37}$

There is no provision made for input from the member, nor is $\mathrm{s} / \mathrm{he}$ given access to the material which the CMRB reviews. It is interesting to question whether the CMRB meets the general duty of fairness required of every administrative tribunal; even a cursory analysis would suggest that it does not. ${ }^{38}$

One of the major factors considered by the CMRB is the "percentage of employability", which is the percentage of current positions for the member's trade, experience and rank that $\mathrm{s} / \mathrm{he}$ could fill notwithstanding the medical condition. ${ }^{39}$ The CMRB uses the following guidelines:

a) If the member is 80 percent employable, then $s /$ he will be retained without career restrictions;

b) If the member is $60-80$ percent employable, then s/he will normally be retained with career restrictions relating to promotion and training; and

Medical Process, supra note 27. A list of factors considered during CMRB deliberations is also found in the Chief of Personnel, Careers and Senior Appointments, Operations Planning Manual (OPM) 118-1 1987, Annex A [hereinafter OPM 118-1], which describes roughly the same factors. A-G (Canada) v. Thwaites (25 March 1994), Reasons for Order 94, T-1629-93 (F.C.T.D.) [unreported] at 7 noted that Thwaites had no notice of the CMRB meeting and was provided no opportunity to make submissions, and that the Board's handling of the case was "most summary". The Court ruled that, as an individual assessment process, it "failed to respect the most basic elements of the duty to act fairly" (at 24). In Miller v. Director General Postings and Careers Officers (17 March 1994), T-2063-93 (F.C.T.D.) [unreported], the Court ruled that a Career Review Board (i.e. non-medical) had a duty of faimess that included, where dismissal was an option, an opportunity to be heard and reasons for the decision. Leading cases on procedural fairness in administrative decisions are Nicholson v. Haldimand-Norfolk Police Commissioners Board, [1979] 1 S.C.R. 311; Cardinal v. Director of Kent Institution, [1985] 2 S.C.R. 643; and Knight v. Saskatchewan Indian Head School Division (1990), 43 Admin. L. R. 157 (S.C.C.). 
c) If the member is less than 60 percent employable, then s/he will be considered for transfer to another military occupation or for release from the CF. ${ }^{40}$

Suitability for another military occupation is primarily influenced by the member's employment limitations, aptitudes, and past performance, and by the requirements of the CF (i.e. the forecast need for personnel in other military occupations). Depending on the degree of medical and functional limitation, the member's ability to meet the General Specifications may become highly relevant to a decision to transfer that person to another military occupation or to release him or her from the Forces. It is on this issue that the majority of cases are taken to Human Rights Tribunals.

It is understood that the abovementioned guidelines are flexible and that other factors will influence the CMRB's decision. For example, the CF is currently considering the possibility of offering an option to members, who would hitherto have been retained in their military occupation with career restrictions, to transfer to another military occupation where they would not be subject to career restrictions. Notwithstanding such flexibility, the question arises, what is the objective and scientific basis for the guidelines? Why are members generally considered for trade transfer or release when they are less than 60 percent employable? Why 60 percent $?^{41}$ For example, consider a large military occupation, such as Administrative Clerk, for which there are many hundreds of positions across Canada. If individuals can fill more than half of those positions without any difficulty, why must they be transferred out of their military occupation or released? An argument often raised at tribunal hearings is the need to be able to rotate people between the more demanding (less attractive) positions and the more popular ones. For example, with the seagoing trades there is a need to maintain a sea/shore ratio to let members have regular postings ashore. ${ }^{42}$

This need for rotation of personnel and for sharing of the arduous postings is a traditional part of military life. It is defensible in terms of the need to maintain morale ${ }^{43}$ and the need to achieve a flexible capability through overlapping job skills and the training of personnel with a broad exposure to the conditions they might face in an emergency. But the fact remains that guidelines, such as those mentioned above, must be assumed to be arbitrary until they are justified by objective evidence.

Medical Process, supra note 27 at Annex C, at 6, para. 15.

This $60 / 80$ percent guideline is under review, which could result in thresholds that are unique for each military occupation and rank.

For example, this was an issue in Levac v. Canadian Armed Forces (1992), 94 D.L.R. (4th) 266 (F.C.A.) [hereinafter Levac]. In that case, medical authorities were of the view (not accepted by the tribunal) that a naval engineer's heart condition posed such a risk as to make him unfit for sea duty, and given the need to maintain a sea/shore ratio, unfit to continue in the Forces.

Some postings, such as Canadian Forces Station Alert, North of the Arctic Circle, a destroyer with a heavy schedule away from home port, or a battalion in Bosnia, place heavy stress on serving members, make normal family life impossible, and prevent normal training required for career progression. Therefore it is generally accepted within the CF that a regular rotation of personnel is necessary to share the arduous postings. 


\section{ISSUES}

\section{A. DISCRIMINATION: THE BFOR AND REASONABLE ACCOMMODATION DEFENCES}

All of the Human Rights Codes and Acts provide a statutory defence to discrimination based on bona fide or reasonable occupational qualification or requirement (BFOQ and BFOR will be used interchangeably ${ }^{44}$ ). Once it is established on the balance of probabilities that an employment rule has directly discriminated on a prohibited ground, the employer may attempt to justify the prima facie discrimination on the basis of a BFOR. ${ }^{45}$ The test for determining when a BFOR is established has been discussed in many cases, but a landmark case of the Supreme Court provides the best terms of reference.

The case of Ontario Human Rights Commission v. The Borough of Etobicoke ${ }^{46}$ involved two firemen employed by Etobicoke who were forced to retire pursuant to a clause in their collective agreement. The termination clearly was discrimination on the basis of age and the issue was whether it was a BFOR. The Board of Inquiry had found that the evidence in this respect was "impressionistic" and noted the inadequacy of general assertions by witnesses that fire fighting is a "young man's game". ${ }^{47}$ The Supreme Court unanimously ruled that a BFOR was not established, stating that the evidence adduced was inadequate to discharge the burden of proof lying upon the employer. It also found that the evidence did not cover the detailed nature of the duties to be performed, the conditions existing in the workplace, and the effect of such conditions upon employees, particularly upon those at or near the retirement age. Justice McIntyre stated:

To be a bona fide occupational qualification and requirement a limitation, such as a mandatory retirement at a fixed age, must be imposed honestly, in good faith, and in the sincerely held belief that such limitation is imposed in the interests of the adequate performance of the work involved with all reasonable dispatch, safety and economy, and not for ulterior or extraneous reasons aimed at objectives which could defeat the purpose of the Code. In addition it must be related in an objective sense to the performance of the employment concerned, in that it is reasonably necessary to assure the efficient and economical performance of the job without endangering the employee, his fellow employees and the general public. ${ }^{48}$

This approach was adopted by the Supreme Court of Canada in Alberta Human Rights Commission v. Central Alberta Dairy Pool, [1990] 2 S.C.R. 489 [hereinafter Alberta Dainy Pool] at 502. See, for example, Canadian Human Rights Act, supra note 1, s. 15(a). Alternately, if the employment rule is "neutral" on its face, but it has an adverse discriminatory effect, then the employer will be required to accomodate the individual to the point of undue hardship. For example: "all employees must work on Saturday" is neutral on its face, but it will adversely discriminate against those for whom Saturday is the Sabbath. This will be discussed further below. [1982] 1 S.C.R. 202, 132 D.L.R. (3d) 14, 3 C.H.R.R. D/781 [hereinafter Etobicoke cited to S.C.R.].

48 Ibid. at 208. 
The test contains two elements: subjective and objective. Very rarely will the subjective element be in issue since to fail that element would be tantamount to finding that the employer created the occupational requirement for ulterior motives unrelated to adequate job performance.

This defence of BFOR was severed from the concept of reasonable accommodation in Bhinder v. Canadian National Railway Company..$^{49} \mathrm{Mr}$. Bhinder was a member of the Sikh religion, which requires him to wear a turban and no other head covering. He was fired when he refused to wear a hard hat. The Court found that the evidence supported a BFOR because of the risk inherent in working in the coach yard. Notably this evidence was less than overwhelming, since it seemed that there was no danger to anyone but Bhinder, and that danger was quite small. The Court further ruled that once a BFOR was found, it was unnecessary to consider the special circumstances of the individual and that there was no need for the employer to accommodate him or her.

The Bhinder rule, that no accommodation was required once a BFOR was found, stood from 1985 until 1990 when, remarkably, it was modified. ${ }^{50}$ The Supreme Court looked at the question of reasonable accommodation again in Alberta Human Rights Commission v. Central Alberta Dairy Pool. ${ }^{51}$ Mr. Christie was an employee of the Central Alberta Dairy Pool who became a member of the World Wide Church of God in 1983. That Church recognizes Saturday as the Sabbath, and ten other holy days throughout the year. Members of the Church are expected not to work on these days. Mr. Christie asked to take unpaid leave on a Tuesday and then on a Monday because these were holy days. The Tuesday was approved but not the Monday because Mondays were especially busy days at the dairy pool; milk that arrived over the weekend had to be processed quickly. When Mr. Christie was absent on the Monday, he was fired. There was evidence that the employer could have accommodated Mr. Christie without undue hardship, since asking for Monday off would be a rare occurrence, and in the case of an employee's illness, it was customary for a supervisor to take over.

The issues were how to apply the BFOR test and whether the employer had to make a reasonable accommodation to the needs of the employee. The majority, repudiating part of the Bhinder decision, ruled that if an occupational requirement discriminates through adverse effect rather than directly, the BFOR is not relevant but there is a duty to accommodate. Adverse effect discrimination means that a rule made for valid business reasons is neutral on its face, and yet it has an adverse discriminatory effect on a particular group based on a prohibited ground. In the Alberta Dairy Pool case the

[1985] 2 S.C.R. 561, 23 D.L.R. (4th) 481, 7 C.H.R.R. D/3093 [hereinafter Bhinder].

In Brossard (Town) v. Quebec (Commission des Droits de la Personne), [1988] 2 S.C.R. 279 [hereinafter Brossard], a case involving the town's anti-nepotism policy, the Court added a qualification to the BFOR test. The Court required that the employment rule be properly designed so as not to place an "unduc burden" on anyone. In that case, the employment rule was struck down as being "disproportionately stringent" (at 311,315 , and 343). However, in subsequent cases, the "reasonably necessary" test enunciated in Etobicoke, supra note 46, fulfils much the same function.

Supra note 44. 
Monday attendance rule was not aimed at any religious group and yet it adversely impinged on a group, members of the Church of God, who were encouraged to observe a holy day on a specific Monday. In this situation, the Court ruled that, rather than look to the BFOR test, it would apply the test of reasonable accommodation to see whether, through compromise, the employer could meet the employee's needs without incurring undue hardship. Rather than having to meet the "reasonably necessary" test for a BFOR, the employer only had to show that the Monday attendance rule (and its inflexibility) was "rationally related to the performance of the job." ${ }^{\text {"52 }}$

\section{Justice Wilson, writing for the majority, said:}

Where a rule discriminates on its face on a prohibited ground of discrimination, it follows that it must rely for its justification on the validity of its application to all members of the group affected by it. There can be no duty to accommodate individual members of the group within the justificatory [BFOQ] test because, as McIntyre J. pointed out, that would undermine the rationale of the defence. Either it is valid to make a rule that generalizes about members of a group or it is not. By their very nature rules that discriminate directly impose a burden on all persons who fall within them. If they can be justified at all, they must be justified in their general application. That is why the rule must be struck down if the employer fails to establish the BFOQ. This is distinguishable from a rule that is neutral on its face but has an adverse effect on certain members of the group to whom it applies. In such a case the group of people who are adversely affected by it is always smaller than the group to which the rule applies. On the facts of many cases the "group" adversely affected may comprise a minority of one, namely the complainant. In these situations the rule is upheld so that it will apply to everyone except persons on whom it has a discriminatory impact, provided the employer can accommodate them without undue hardship. ${ }^{33}$

\section{Later, in commenting on Bhinder ${ }^{54}$ and summarizing, she said:}

[O]nce a BFOR is established the employer has no duty to accommodate. This is because the essence of a BFOR is that it be determined by reference to the occupational requirement and not the individual characteristic. There is therefore no room for accommodation: the rule must stand or fall in its entirety.

For these reasons, I am of the view that Bhinder is correct in so far as it states that accommodation is not a component of the BFOR test and that once a BFOR is proven the employer has no duty to accommodate."s

Ibid. at 507. accommodate without undue hardship is part of the process of proving a BFOQ. Vizkelety is of the view that these two views are largely reconcilable, (see B. Vizkelety, "Human Rights Discrimination in Employment - Reasonable Accommodation Revisited: Alberta Human Rights Commission v. Central Alberta Dairy Pool" (1991) 70 Can. Bar Rev. 335), however, I am of the view that they are quite distinct. 
In Alberta Dairy Pool, the Court ruled that the employer could accommodate an occasional Monday absence without undue hardship, and so the complaint was upheld.

The relationship between the BFOR and reasonable accommodation defences continue to develop. An important related issue is the extent to which the individual's circumstances must be taken into account. Thus far it would seem that, while they are central to accommodation under adverse effect discrimination, they are not relevant to direct discrimination or a BFOR. One further element has been added to the test for a BFOR: is individual testing impractical? In Saskatchewan (Human Rights Commission) v. Saskatoon ${ }^{56}$ the Supreme Court clarified that, while individualized testing is not an absolute requirement to the establishment of a BFOR, the employer may not be able to establish one without showing that individualized testing was not a practical alternative to adopting a discriminatory employment rule. ${ }^{57}$ In Wardair Canada Inc. v. Cremona ${ }^{58}$ the Federal Court of Appeal applied this test, ruling that, in establishing a BFOR with respect to uncorrected visual acuity for a flight attendant, there was an onus on the employer to demonstrate that it could not test individually without undue hardship. ${ }^{59}$

Perhaps the relationship between a discriminatory occupational requirement and a BFOR or reasonable accommodation can best be summarized graphically. ${ }^{60}$

Discrimination on Prohibited Ground

\begin{tabular}{|l|l|}
\hline \multicolumn{1}{|c|}{ Directly } & \multicolumn{1}{c|}{ Adverse Effect } \\
\hline $\begin{array}{l}\text { Must prove practice is "reasonably necessary" } \\
\text { (objective test) }\end{array}$ & Must prove practice is "rationally related" \\
\hline $\begin{array}{c}\text { Must prove BFOR: } \\
\text { - subjective and objective tests } \\
\text { - No accommodation of individual employee } \\
\text { required once BFOR proved. }\end{array}$ & $\begin{array}{l}\text { Must prove reasonable accommodation to point } \\
\text { of undue hardship. }\end{array}$ \\
$\begin{array}{c}\text { - Proof of BFOR may require proof that } \\
\text { individual testing would impose undue } \\
\text { hardship. }\end{array}$ & \\
\hline
\end{tabular}

[1989] 2 S.C.R. 1297.

Ibid. at 1313.

(1993), 146 N.R. 69 (F.C.A.) [hereinafter Cremona].

Ibid. at 73-74.

so These judicially developed parallel tests for justifying discrimination can be seen as unnecessarily complicated. Watkin has argued that the tests can and should be simplified to a single test patterned after the jurisprudence regarding s. 1 of the Charter. See K. Watkin, "The Justification of Discrimination under Canadian Human Rights Legislation and the Charter: Why So Many Tests?" (1992) 2 N.J.C.L. 63. 
The issue of a BFOR has been considered in a case relating to the CF Reserve Force. In Galbraith v. Canadian Armed Forces, ${ }^{61}$ a man with a continent ileostomy was refused enrolment as an artilleryman in the Reserve Militia. His large intestine had been removed and a small pouch had been constructed inside his small intestine, which had to be drained by catheter twice a day. The ileostomy had little impact on his life, but it rendered him more sensitive to water loss and to imbalances in electrolytes. This made him less likely to be able to cope with the stress of life as an artilleryman and created a sufficient risk of "employee failure" such that the absence of a continent ileostomy was found to be a BFOR for the position of artilleryman. Even though the Reserve Force artilleryman trains less often and serves under distinct conditions of service, the tribunal was unwilling to distinguish between Regular Force and Reserve Force positions for the purpose of determining a BFOR.

\section{B. ASSUMPTION OF RISK}

It is useful to review the issue of whether a disabled employee should be permitted to perform a role even though $\mathrm{s} / \mathrm{he}$ assumes some increased risk of personal injury (which may or may not increase the risk to someone else). In other words, should a person be entitled to assume the risk to oneself? There is a strong argument to be made against overly paternalistic protection; however, I would suggest that the weight of the case law is against allowing an individual to assume any significant degree of risk.

One line of cases began with Air Canada v. Carson, ${ }^{62}$ which held that some risk, especially if it is minimal, might be acceptable to ensure that the disabled enjoys equality of opportunity. ${ }^{63}$ Some tribunals have followed this proposition in DeJager v. D.N.D. ${ }^{64}$ Nowell v. C.N.R., ${ }^{65}$ and Mackenzie v. Quintette Coal. ${ }^{66}$ In DeJager, for example, the complainant was a boatswain in the Navy, and between 1980 and 1982, he suffered four asthma attacks. The Department downgraded his medical category, based on his asthmatic condition, but the tribunal found that it did not conduct an individual assessment of his ability to do the job. There was, however, evidence that one of the attacks which was treated at the shore hospital "could not have been adequately treated aboard ship." ${ }^{167}$ In other words, if the attack had occurred while DeJager had been at sea, where there were less adequate treatment facilities and no doctor, he would have been at significant personal risk. The tribunal nonetheless held that a BFOR was not established. The tribunal relied on two authorities which may have been sound at the time but which today would fail to support such a finding.

First, the tribunal relied on the Federal Bona Fide Occupational Requirement Guidelines $^{68}$ which provide a BFOR when there is a safety hazard for "the employees

Supra note 6.

[1985] I F.C. 209 (C.A.).

Ibid. at 230-32.

(1986), 7 C.H.R.R. D/3508 (Fed.) [hereinafter DeJager].

(1987), 8 C.H.R.R. D/3727 (Fed.).

(1987), 8 C.H.R.R. D/3762 (B.C.).

Supra note 64 at D/3512, para. 27997.

Bona Fide Occupational Requirement Guidelines, S.I. 82-3, dated 13 January 1982. 
of that employer" or the general public (as opposed to the individual). The guidelines also require an employer to show that if employment of the handicapped person would cause an "unreasonable risk to himself or herself" that it would "likely result in the disruption of the employer's business." In other words, the Guidelines impliedly excluded personal risk as proof of a BFOR unless the employer could prove the additional element of disruption to business. But these guidelines have now been revoked ${ }^{69}$ and, as will be described below, the Supreme Court has used a different test. Second, the tribunal in DeJager relied extensively on the Federal Court Trial Division decision in Mahon v. Canadian Pacific Ltd. ${ }^{70}$ both for its guidance on assumption of risk and for its expansive interpretation of the Canadian Human Rights Act. However, the Mahon case was subsequently overturned by the Federal Court of Appeal specifically on the question of risk. ${ }^{71}$ The appellate court ruled that even a slight possibility of risk to the general public was a "real" risk within the meaning of Bhinder. ${ }^{72}$ Although Bhinder was, in part, reversed by the Alberta Dairy Pool case, I am of the view that it has not been reversed on the question of risk. ${ }^{73}$

In $A-G$ (Canada) v. Thwaites, ${ }^{74}$ the tribunal had gone so far as to require evidence of "substantial" risk, but the Federal Court Trial Division effectively rejected this, ruling that, in the context, this could only be interpreted as meaning something greater than "slight or negligible".

It should be recalled that in the Etobicoke case, the Supreme Court described the objective part of the BFOR test as follows:

In addition it must be related in an objective sense to the performance of the employment concerned, in that it is reasonably necessary to assure the efficient and economical performance of the job without endangering the employee, his fellow employees and the general public."s

From this authoritative pronouncement it seems clear that the degree of risk is not particularly important, but rather the mere presence of a real risk to the employee or anyone else. In the context of the protection of the public, the Court in Etobicoke stated:

In an occupation where, as in the case at bar, the employer seeks to justify the retirement in the interest of public safety, to decide whether a bona fide occupational qualification and requirement has been shown the board of inquiry and the court must consider whether the evidence adduced justifies the conclusion that there is sufficient risk of employee failure in those over the mandatory retirement age

S.I. 88-184, dated 12 October 1988.

(1986), 7 C.H.R.R. D/3278 (Fed.) [hereinafter Mahon].

(1987), 8 C.H.R.R. D/4263 (Fed. C.A.) [hereinafter Mahon Appeal].

Supra note 49.

I am supported in this by the Canadian Human Rights Tribunal decision in Husband v. Canadian Armed Forces, (1992) 15 C.H.R.R. D/197 [hereinafter Husband] affirmed at the Federal Court of Appeal level, supra note 9. Also see Attorney General of Canada v. Robinson (1994), 170 N.R. 283 (Fed. C.A.) [hereinafter Robinson]. 
to warrant the early retirement in the interests of safety of the employee, his fellow employees and the public at large. ${ }^{76}$

In the Mahon case, the Court summarized the effect of the Etobicoke and Bhinder decisions as follows:

The effect of those decisions, in my view, is that, a fortiori, a job-related requirement that, according to the evidence, is reasonably necessary to eliminate a real risk of a serious damage to the public at large must be said to be a bona fide occupational requirement.

The decision under attack [the Trial Division decision on Mahon], it seems to me, is based on the generous idea that the employers and the public have the duty to accept and assume some risks of damage in order to enable disabled persons to find work. In my view, the law does not impose any such duty on anyone. ${ }^{n}$

The test, which was summarized in Mahon, was applied by the Manitoba Court of Queen's Bench in Loveday v. Baker Manufacturing $L t{ }^{78}$ In that case, the complainant was fired from a job that required heavy lifting because of a previous back injury. The Court said that even if the employee were willing to assume risks of injury to himself,

No employee has the right to risk serious injury to himself, and no employer should be required to employ someone whose physical condition subjects him or her to the risk of more than trivial injury. ${ }^{79}$

I conclude that the Federal Court of Appeal, in the Mahon decision, corrected its position in Carson and returned to the "real risk" test enunciated by the Supreme Court in Etobicoke and Bhinder. Therefore, tribunal decisions, such as DeJager, which follow the Carson decision regarding "risk", are questionable. ${ }^{80}$

\section{THE ENVIRONMENTAL SPECIFICATIONS}

By definition, the requirements imposed by the Environmental Specifications are necessary only when employed within a given environment. However, since integration in 1968, service members have been transferred between environments without their consent, as required by the exigencies of the CF. What if a member was perfectly able

Ibid. at 209-10 [emphasis added].

Supra note 71 at D/4267, paras. 33490-91. The Federal Court of Appeal, in Husband, reemphasized that the test for risk laid down in Etobicoke remains "unchallenged and unimpaired". See Husband, supra note 73. Carson was also discussed in Seguin v. Royal Canadian Mounted Police (1989), 10 C.H.R.R. D/5980 [hereinafter Seguin] at p. D/6003 and the Mahon test was adopted.

Loveday, ibid. at $\mathrm{D} / 3146$.

On the other hand, it also seems clear that a mere marginal increase in risk will not support a BFOR. See Alberta Dairy Pool, supra note 44 at 513, and Canada (Attorney-General) v. Rosin, [1991] 1 F.C. 391 (C.A.) at 411. 
to perform his or her job in one environment but discovers, on transfer to another environment, that $\mathrm{s} / \mathrm{he}$ cannot meet the demands imposed by the Specification of that new environment?

Suppose a member of a "green" military occupation, meaning an occupation that serves in all environments, ${ }^{81}$ is posted to an army field unit. To make the example a little more concrete, we could consider an administrative clerk posted from a ship based in Halifax to the artillery regiment at an Army base. As of the posting, s/he switches from a sea to a land environment, with the corresponding change in Environmental Specification. S/he must learn a number of new skills and must be capable of completing the ten mile forced march on consecutive days. What if $s /$ he cannot? The requirement arises not from the core of his/her military occupation, but rather from the physical demands of performing that trade as a member of an army field unit. To put a finer point on it, we could consider the corresponding example of the administrative clerk posted from an Air Base to replace the previous person on the ship. What if $s / h e$ is incurably seasick?

Assuming that the Environmental Specifications are reasonable requirements to impose on everyone working in that unit, then it may be that the physical capability can be defended as a BFOR of that job in that unit. The question is: what consequences should arise for an individual who cannot meet the Environmental Specification? The case of incurable seasickness seems easiest to answer since it is clearly an immutable disability. ${ }^{82}$ While the ability to go to sea might be easily justifiable as a BFOR, the logical solution, and the one that the law would require, would be to return the individual to non-seagoing employment. This would be equivalent to a medical category with an environmental limitation and I am informed that it is the current practice in the $\mathrm{CF}^{83}$ The inability to meet a physical requirement of the land Environment Specification is a little less clear. For most healthy soldiers this failure will not be an immutable problem; with sufficient training and with the emphasis placed on team cooperation, most should be able to eventually complete the tests. In fact, this is the solution found for virtually all such cases: remedial training and second attempts. But what of the hypothetical case of the individual who, because of some physical handicap, will never be able to complete the ten mile forced marches and yet can quite readily practice his/her military occupation in another environment. The problem is that the CF

By "green" trades I mean those which have no particular Environmental affiliation. For example, administrative clerks, supply technicians, finance clerks, legal officers, logistics officers, and chaplains can and do serve in all three environments. By contrast, infanteers, pilots, and sonarmen have clear affiliations with their branch of the service even though they may occasionally serve in another environment.

82 Immutability is one of the criteria used by courts and human rights tribunals to identify a disability protected by human rights legislation. See: Greene v. Union Pacific Railroad Company. 548 F. Supp. 3 (U.S. District Ct. 1981); Jefferson v. Baldwin (1976), (B.C. Bd. Inq.) [unreported]; and Hamlyn v. Cominco Lid. (1990), 11 C.H.R.R. D/333 (B.C.). In this context, immutable seasickness is a useful contrast to the difficulty one might experience in completing the Army's forced march because of a lack of physical conditioning.

83 This information was received in anecdotal form from a variety of military personnel and is based on their experience as officers in naval environments, as career managers, and as military medical personnel. 
has, by virtue of integration, no environmental distinctions within the "green" trades. The environmental medical limitation is about the only tool the CF has for keeping an individual out of an environment for which $s /$ he is not qualified. It seems unfair to punish an individual by means of career (promotion) limitations for simply being incapable of meeting an environmental qualification when that person can adequately perform his/her military occupation in the other environments. The key is immutability: if remedial training can help, then the problem can be solved, but if it cannot, then an environmental limitation should be imposed. If this restricts the individual's employability "too greatly", then a military occupation transfer or release could be considered, but otherwise, the environmental limitations should not entail career limitations. The phrase "too greatly" translates into the legal test for a BFOR, that is, is this environmental requirement so important that it is reasonably necessary for the efficient and economical performance of the job, and that the standard be met by all service members of this military occupation? If not, then the inability of the member to meet this requirement cannot justify any career limitation.

\section{UNIVERSALITY OF SERVICE — IS EVERYONE A SOLDIER FIRST?}

One of the most striking aspects of CF Medical System from a human rights and equality point of view is the fact that every member of the Forces must, with some exceptions, be capable of performing all of the duties in the General Specification that apply to him or her. The only broad distinction is in the separate General Specifications for officers and non-commissioned members. The only explicit exceptions are: (a) the possibility that an applicant may be excused from meeting the Common Minimum Enrolment Standard (CMES) if s/he possesses special qualifications, and (b) the exception that may be made by a CMRB for an experienced serving member whose medical category falls below the minimum for his/her military occupation but who is still capable of performing most of the functions related to that trade as defined by the Military Occupation Specifications (as opposed to the generally narrower requirements of his/her present job).

This remarkable requirement that $\mathrm{CF}$ members be capable of performing all of the General Specifications or General Military Duties (GMD) is a clear departure from the normal approach to analyzing job requirements under the Canadian Human Rights Act. ${ }^{84}$ Normally the employer would be asked to describe in detail the tasks routinely required in the course of a job and then to explain why the absence of a particular mental or physical disability is a BFOR. In the case of the Armed Forces this job description seems parallel to the Military Occupation Specifications, while the General and Environmental Specifications seem an additional burden on the individual. However, I will suggest that all three of these Specifications form a legitimate part of the job description and, while quite different from most job situations, are not entirely unique. Parallels can be found in the police forces, which must similarly prepare their personnel to respond flexibly to emergency situations for which only general response plans can be made. 
I must admit that one difficulty with my argument is, as discussed above, some of the General Specifications, particularly those for the officers, are not described with any precision. There is a real danger that they could be applied inconsistently and it seems difficult to relate them all to specific requirements, either in war or peace-time roles. For example, the requirement for "physical reserves" sufficient to "meet any emergency" is far too general to be of any use. Does it refer to the physical stamina to do physical work for long periods without rest or food? Or does it refer to the physical stamina to perform one's normal duties for longer periods than is normally expected? It should be possible to describe this in far more concrete terms. The present CF general fitness test is called the EXPRES program and consists of aerobic, muscular strength, muscular endurance tests, and body composition measurements, but it is considered an inadequate test for combat arms troops. ${ }^{85}$ As discussed above, the Land Environmental Specification imposes additional physical tests such as the 10 mile forced march on consecutive days. Perhaps this merely emphasizes that different standards are required for members of the "Army" ${ }^{86}$ than for other members of the CF. However, it does not prove that these other members need not maintain a level of fitness consistent with their GMD, such as Base Defence Force. Perhaps it demonstrates the contrary: the GMD standard expressed in the General Specifications is not attempting to make "combat soldiers"87 out of every service member; it merely aims at some lower level of fitness which is consistent with emergency military duties in less demanding environments. I would, however, readily concede that the General Specifications for officers are not presently drafted with sufficient precision and should be revamped.

The concept of Universality of Service, as expressed in the General Specifications, basically requires that every service member have sufficient physical and mental capabilities to be able to perform a certain core of duties at all times and places, even though they are not particularly related to their primary job. It is founded on the premise that every member of the Armed Forces is a "soldier first" and practices his or her trade second. Certainly this is true in the sense that every unskilled tradesman who enters the CF trains first at a "boot camp" or Recruit School to learn those basic military skills such as weapons handling and firing, fire fighting, drill and emergency first aid. It is only later that the trade skills are taught. It is true in the sense that every member of the forces is united by a common sense of esprit de corps and by the "unlimited liability" of being bound "to perform any lawful duty" ${ }^{188}$ even to the point of suffering injury or death. This chilling reminder, found in the General Specifications,

S.W. Lee, P. Chahal, M. Singh \& G. Wheeler, "Physical Fitness and Performance Standards for the Canadian Army" (1990) 19:5 Canadian Defence Quarterly 31 at 33.

Since the Land Environmental Specification applies to every member serving in that element, I use the term "Army" to include all of the support personnel who serve, at a given time, with the Army. As I have said above, these support personnel are fully integrated into combat units and have a real possibility of facing front-line combat conditions in a crisis.

I use the term "combat soldier" loosely here to refer to any member who faces a real possibility of front-line combat. In a more technical sense, the term "combat arms" trades refer only to the trades: infantry, artillery, and armoured corp.

Supra note 5, s. 33(1). 
is more than rhetoric; it is a core commitment for every member of every armed force in the world.

The principle of "soldier first - tradesman second" was adopted and applied in Rivard v. Department of National Defence. ${ }^{89}$ Rivard had served for six years in the militia (Reserve Force) as a tank crewman before joining the Regular Force. After serving four years in the Regular Force, he injured his knee. Because of the injury, he was unable to run, to walk for longer than an hour, to stand for prolonged periods, or to jump. He was found unfit (in the sense of being unable to fulfil essential requirements) for his military occupation, was refused a transfer to administrative clerk and was released from the CF. The tribunal held that he could not continue employment in the $\mathrm{CF}$ even as an administrative clerk. In upholding a BFOR, the tribunal stated:

A soldier is first and foremost a soldier, and if a state of war exists, he must be able to perform the duties of a soldier for which he was trained. It follows, therefore, that an individual who occupies, for example, an administrative position within the army cannot forget his main vocation, even if his daily functions do not require him to carry a gun in the same way as a soldier in the field. ${ }^{.0}$

The tribunal found that even outside of these combat-type duties, the complainant would be unable to perform the day-to-day duties of an administrative clerk, and so a BFOR was found. Even an administrative clerk is liable to perform the GMD in an emergency and must train for them in the interim.

The "soldier first" principle was also applied in Gaetz v. Canadian Armed Forces." Gaetz was a supply technician who became an insulin dependent diabetic and was consequently released from the $\mathrm{CF}$. The tribunal supported this release based on the fact that supply technicians in the CF, unlike civilian equivalents in DND, are regularly posted to army combat units and naval units where conditions of service and job requirements in an emergency or combat conditions would be incompatible with his disability. When an army unit goes into the field, every member of the unit, including the supply technician, will live under arduous conditions, work long hours, perform physically demanding jobs, and put up with unpredictable accommodations, meals, sleep periods, and amenities. In the context of an insulin dependent diabetic, it was crucial that the work load could not be anticipated and was not under the individual's control. The review tribunal applied the "real risk" test and upheld the BFOR.

The tribunal in Husband v. Canadian Armed Forces" similarly applied the "soldier first" principle in upholding a minimum uncorrected vision requirement for a military musician. In other words, even though the complainant could perform the essential duties of a musician, including the GMD, using glasses, it was a BFOR to be have a minimum uncorrected vision since glasses could not be relied upon in certain military

89 Supra note 22.

$9 \quad$ Ibid. at D/142, para. 21.

91 (1989), 10 C.H.R.R. D/5902 (Fed.), affd on review (1989), 10 C.H.R.R. D/6375 (Fed.) [hereinafter Gaetz].

92 Husband, supra note 73. This was upheld by the Federal Court of Appeal, supra note 9. 
activities such as Base Defence Force and when preparing for a chemical attack. In this regard the tribunal said:

It is true that many individual members of the CAF, both in the musician trade and in many other trades, may perform satisfactorily in the day to day duties related to his/her trade or occupation, perhaps spending an entire career without ever facing the military crisis for which he/she has been hired and trained. Nevertheless, the military role of the CAF is a critical one. It is vital that the function be carried out competently if and when required - failure to perform adequately under those circumstances would have serious effects, and the risk of failure is not one that is justified or acceptable.

It is tempting, in a country like Canada which is relatively free of internal unrest and, until recently, had not been at war for many years, to minimize the importance of the military role of the CAF and the risk of danger to its members in carrying out that role. Talk of war, hostilities and fighting can seem over-dramatized, and possibly even farfetched. However, between the hearing of the evidence in this matter and the writing of this decision we have had two very striking examples of the continued need to retain the military and to maintain its members at a level of preparedness where they can be deployed on a moments notice. The first example of the use of the military related to the civil unrest at Kahnawake and Kahnisatake [sic] and the second example was on the use of our armed forces is the Persian Gulf war.

Based on all of the evidence, I am satisfied that the primary role of all regular members of the CAF is to protect the interests of Canada, Canadians and Canadian Allies with physical force, if necessary. While other roles may be assumed by various members of the CAF when our country is not at war, the primary obligation and purpose of the CAF is to maintain that war time preparedness. It is therefore my opinion that the defence of BFOR as it relates to the occupation which is the subject matter of this complaint, must be related to the military aspects of being a regular member of the Armed Forces as well as the occupation of being a musician in the CAF. ${ }^{33}$

The Federal Court of Appeal upheld this line of authority in Attorney-General of Canada v. St. Thomas. ${ }^{94}$ In that case, a Construction Engineering Procedures Technician (CEP Tech.), who completed eleven years of military service and had a history of mild asthma attacks, underwent a routine medical screening before a posting to Alert, NWT. Because of concern for his asthma, Mr. Thomas' medical category was lowered to a level which precluded physically demanding duties. This was also below the minimum standard for his CEP Tech military occupation and he was subsequently released from the CF. A Human Rights tribunal ruled that the CF had discriminated on the basis of disability and that no BFOR had been proved.95 In overturning the tribunal's decision, the Federal Court of Appeal stated:

In my view, examination of this issue must take account of a contextual element to which the Tribunal did not give sufficient consideration. It is that we are here considering the case of a soldier. As a member of the Canadian Forces, the Respondent, St. Thomas, was first and foremost a soldier. As such 
he was expected to live and work under conditions unknown in civilian life and to be able to function, on short notice, in conditions of extreme physical and emotional stress and in locations where medical facilities for the treatment of his condition might not be available or, if available, might not be adequate. This, it seems to me, is the context in which the conduct of the Canadian Forces in this case should be evaluated.\%

Another illustration may be found in examining the military occupations of CF personnel recently deployed to the Middle East during the war to liberate Kuwait. Annex B contains a breakdown of CF personnel, by military occupation, that served in the Persian Gulf during the conflict. ${ }^{97}$ It should not be surprising that the heaviest contributing military occupations for NCMs and officers respectively were Infantry and Maritime Surface. However, beyond that, the numbers are a little surprising, because of the heavy representation from such sedentary occupations as Medical Assistant, Supply Technician, Nurse, Doctor, and Logistics officer. The top five contributing occupations for officers and NCMs were:

\section{Officers}

1. Maritime Surface (Navy) (76)

2. Pilot (61)

3. Nurse (52)

4. Medical doctors (34)

5. Logistics (21) and Maritime Engineer (21)

\section{NCMs}

Infantry (256)

Medical Assistant (100)

Weapons Tech. (Air) (93)

Boatswain (89)

Supply Tech. (87)

Other administrative military occupations were also fairly heavily represented such as: administrative clerk (52), finance clerk (12), cook (59), steward (40), and postal clerk (8). Given that this was a real conflict in which every member was at risk (of lethal chemical attack and terrorist attack, at a minimum) and every member had to assume responsibility for his/her own personal security and defence, and in many cases had to contribute to perimeter security, it confirms the point that every member of the CF must be capable of performing the core of military duties (i.e. must be a "soldier first"). Even three lawyers from the Judge Advocate General's office were deployed with the CF contingent. They participated in law of war planning as well as negotiations with host countries and the more mundane disciplinary and civil law matters. But at the same time they had to be qualified in the use of a personal firearm (a $9 \mathrm{~mm}$. pistol) and be capable of defending themselves against a chemical and other forms of attack.

Another interesting way of looking at the data is to look at the number of military occupations represented in the contingent that went to the Gulf. Out of $102 \mathrm{NCM}$ military occupations, 81 were represented, albeit some by only one member, and 21 were not represented. Among those military occupations not represented were Search and Rescue Tech., Topographic Surveyor, Plumber Gas Fitter, Dental Hygienist, and

Supra note 94 at 677 [emphasis in original].

This data was provided by LCol K.E. Watkin, then Director of Law/ Human Rights and Information, Office of the Judge Advocate General, NDHQ. The numbers in brackets represent the numbers of personnel. 
Musician. However, the point which seems most significant is that the vast majority of military occupations (79 percent) were called on to send members to this relatively limited conflict to which Canada sent a relatively small force (in comparison with some other NATO members, for example). It does reinforce the fact that members of the Force would be naïve to forget that their job explicitly includes the potential for involvement in a war and the possibility that they will have to defend themselves, their fellow soldiers, and their country.

The last case I will touch upon that declined to apply the concept of universality is Levac v. Canadian Armed Forces. ${ }^{98}$ Chief Warrant Officer (CWO) Levac was an Engineering Chief Technical Inspector, normally the senior non-commissioned engineer on board a naval ship, who developed coronary artery disease. Despite a family history of heart disease he had good exercise tolerance, no symptoms and had never been hospitalized for the condition. He made all the life-style changes to improve his chances of survival (smoking, cholesterol, and alcohol) but was still assessed as having a 8-10 percent chance of having a heart attack within five years. He was released from the CF because he was judged unfit to go to sea. Although he was at the time serving in a shore job, the logic was that a rotation between sea and shore jobs (the sea/shore ratio of time) had to be maintained or morale would be adversely affected. But here is where the evidence began to contradict the logic: Levac testified (apparently uncontradicted) that although he was due to go to sea, there were no sea-going jobs available. In fact, the evidence showed that the CF were having real difficulty replacing him at his shore job and so had to delay his release for a year. There seemed to be no argument that he was fit to do a shore job and so, assuming his unfitness for sea, was fitness for sea a real part of his job? The concept of universality demanded that he be fit to go to sea since that is a normal part of an engineer's job and the sea-shore ratio must be maintained. However, in this particular case it seemed doubtful that there was any real need, rationale or even opportunity to send him to sea. This far then I would submit that the case is correct: it simply requires that the concept of universality be applied subject to an individual assessment of the likelihood that the person will have to perform the role in question. In my view this was sufficient to decide the case and the tribunal need not have gone farther. It is not entirely clear what standard of risk the court applied because it balanced the medical assessment of the chances of a heart attack (8-10 percent) against the lack of symptoms, life-style changes etc. and concluded that the medical evidence was not "real or of sufficient weight"99 to justify the discriminatory practice. This may just be a confused way of saying that the medical evidence did not prove a "real" risk. Unfortunately, in my view, the tribunal also made an error in applying the law. With respect to the question of accommodation, the tribunal considered the Alberta Dairy Pool case and decided that, even though CWO Levac was clearly the subject of direct discrimination rather than adverse effect discrimination, the CF had a duty to accommodate his disability to the point of undue hardship. Unfortunately, the tribunal missed the point of the Alberta Dairy Pool case since it made clear that accommodation is only required in the case of adverse effect discrimination. I would suggest that the primary point to be taken from the Levac case 
is that universality must be tempered with an assessment of the likelihood that the individual will be called on to perform the duty in question.

The tribunals and courts have in a number of cases declined to apply the principle of "universality of service". They have not so much rejected the validity of the concept as they have distinguished it and found that it did not apply or could not justify release from the CF in some circumstances. The legal reasoning in DeJager ${ }^{100}$ suffers from certain flaws, as discussed above. In addition, it seems to have unfairly characterized the evidence as described in the reasons. The tribunal considered that the CF based its decisions on "stereotypical assumptions on the performance of asthmatics." ${ }^{101}$ It noted that all cases of asthmatics reviewed by the CMRB have resulted in release but failed to note that this may only reflect that non-serious cases are not referred to the CMRB; in other words, the first level medical assessments may generally be accurate. Certainly, in this case, the complainant was not referred to CMRB until after his third asthma attack requiring medical treatment, at which time he had to be hospitalized because he was "dramatically short of oxygen" and a "very sick man". ${ }^{102}$ The evidence also seemed uncontroverted that boatswains, as a trade, are the "professional seamen of the navy", ${ }^{103}$ that sudden incapacitation of a boatswain in a seagoing evolution could easily endanger and injure the complainant and others, and that if the third attack had occurred while the complainant had been at sea he could not have been adequately treated aboard ship. ${ }^{104}$ From all of this it seems quite unfair to say that the CMRB decision was not based on a consideration of this individual's capabilities. Even the Human Rights Commission's doctor, who minimized the chance of a recurrence (note: the fifth attack occurred five months after this prediction), recognized an increased risk at an isolated post. Therefore, although this tribunal declined to apply the concept of universality, its decision must be viewed as suspect because of its heavy reliance on the now repealed guidelines and its questionable assessment of the evidence.

In general, tribunals have accepted the concept of universality: that members of the Armed Forces must be soldiers first and must be physically and mentally fit to perform their soldierly duties in an emergency. They have, however, been uncomfortable imposing this requirement when the facts militate against it. ${ }^{105}$ In cases where the individual is, by reason of age, seniority, or other circumstance, quite unlikely to have to fulfil any more demanding role than his/her normal job, the tribunals have shown an understandable tendency to define the BFOR only in terms of the day-to-day job and to rely on a need for individual testing to prevent the CF from imposing an any more rigorous standard. On occasion, in my view, they have gone too far and have placed both the individual and the CF in an impossible position, such as forcing the CF to

Supra note 64.

Ibid. at D/3516, para. 28018.

Ibid. at D/3512, para. 27997.

Ibid. at D/3509, para. 27966.

lbid. at $\mathrm{D} / 3512$, para. 27997.

Examples of such cases are DeJager, supra note 64. In my view, none of these cases rejected the concept of universality of service; rather, they disallowed the BFOR because the facts of the case could not support it. 
rehire a boatswain/seaman who cannot be sent to sea. ${ }^{106}$ But the general flow of the cases has shown a reassuring willingness to let the military maintain its "militariness", as long as it does not attempt to impose unrealistic standards in the name of administrative convenience.

One further theme deserves attention under the heading of "universality of service". A job requirement can be upheld as long as it is a real part of the job, even though it may only be a remote contingency - even though it may not have occurred in decades and may not occur with any predictability. A leading case on this concept is Seguin v. Royal Canadian Mounted Police. ${ }^{107}$ The case has some similarity to the Husband ${ }^{108}$ case since it turned on a requirement for RCMP static guards to have a specific level of uncorrected vision. One of the roles of static guards is to guard against terrorist attacks in such locations as airports and V.I.P. residences, although none have ever had to defend against such an attack or fire a shot in a real threat situation. The tribunal upheld the requirement saying:

While the use of deadly force is going to be rare, it is the criticality of its function, not frequency, that must be considered when assessing the need for visual standards. We have seen that terrorist attacks in Canada have become a real risk, not a mere hypothetical or speculative one. ${ }^{109}$

And later:

Again, the function of RCMP static guards is peculiar in that they may perform satisfactorily in their day-to-day duties, perhaps spending an entire career without ever facing a crisis for which they have been hired and trained. "Follow-up" statistics of job performance for static guards . . . could be misleading. Moreover, the risks involved in such experimentation would be unacceptable."

The parallel I would draw to the Armed Forces is that a member of a support trade may go for years or even an entire career without having to defend his/her base against a terrorist attack, or put out a real fire in his/her ship, or deploy with an expeditionary force to the Persian Gulf. But the fact is that these are real threats for which s/he trains and which must be prepared to face.

It would not be a reasonable accommodation to let some disabled members of the Forces take sedentary jobs, such as postings at CFB Ottawa, excused from Base Defence Force duty, field and sea-going postings, and all deployments to potential war zones. It is not feasible simply to let the able-bodied members do the more physically demanding and dangerous jobs. First, this would reduce the flexibility and depth or "bench-strength" of the CF. The CF would not have the same capacity to fight (or deter) a conflict, mount a peace-keeping force, respond to emergencies such as natural disasters, provide aid to the civil power, or conduct penitentiary patrols. Second, the 
question must be asked, if a job is entirely sedentary with no responsibility to respond to attacks, emergencies, deployments, or conflicts, then why should it be filled with a serviceperson? Without intending any disparagement, I would suggest that this is exactly the kind of job that we should fill, at lower cost," In my view, it is an integral part of being a member of the Armed Force that the person be trained, capable and willing to "go in harm's way".

\section{E. NON-COMMISSIONED MEMBER (NCM) VERSUS OFFICER RELEASE RATES}

Although all career medical decisions in the CF are reviewed at NDHQ, there are separate CMRBs for officers and NCMs. The recent review of the Career Medical Process $^{112}$ discovered that the release rate for the officer CMRB was much lower than that of the NCM CMRB. The statistics are as follows: ${ }^{113}$

Release Rates

\begin{tabular}{||l|l|l|l|l||}
\hline \multirow{2}{*}{} & \multicolumn{2}{|c|}{ officer CMRB } & \multicolumn{2}{c||}{ NCM CMRB } \\
\cline { 2 - 5 } & Retained* & Released & Retained* & Released \\
\hline 1987 & $91.4 \%$ & $8.6 \%$ & $71.1 \%$ & $28.9 \%$ \\
\hline 1988 & 90.8 & 9.2 & 61.8 & 38.2 \\
\hline 1989 & 89.5 & 10.5 & 61.7 & 38.3 \\
\hline
\end{tabular}

* Retained includes those retained with and without career restrictions plus those transferred to other occupations.

Remarkably, the release rate for NCMs is almost four times that for officers. The Review found that a number of factors ${ }^{114}$ influenced this disparity, some of which are justifiable and some of which reveal problems in the system:

a) More of the NCM military occupations require a high geographical and occupational factor than officer occupations. 57 percent require G2 or $\mathrm{O} 2$ whereas only 27 percent of the officer occupations do. This, I would say, is a justifiable difference which would tend to lead to higher release rates for NCMs.

b) A large proportion of the cases considered by the NCM CMRB are combat arms trades: 56 percent of the cases considered in 1989, representing 27 percent of the releases. Since the academic and other aptitude entry standards are lower for the for the service person related to GMD, specialty and emergency training, health benefits, and the regular relocation of the member and his or her family.

$112 \quad$ Medical Process, supra note 27.

$113 \quad$ Ibid. at Annex C, Appendix 5.

is. Ibid. at Annex C, at 4-5. 
combat arms trades than many of the other trades, a combat arms member who drops from G2-O2 to G2-O3 will often not be employable in another trade because of a lack of academic aptitude, rather than for medical or disability reasons. This will tend to increase the number of release recommendations from the NCM CMRB in relation to the officer CMRB. In my view, this is also a justifiable difference.

c) Many of the officer occupations have experienced shortages in recent years, which has influenced the CMRB to retain officers with medical conditions on the boundary of the permissible limits. In my view, this is a permissible factor in the employer's decision and the practice is justifiable, although in an extreme case it would amount to a redefinition of the BFOR.

d) Finally, the Review highlighted three practices of the officer CMRB which I will assess collectively, because they highlight the questionable inflexibility of the NCM CMRB. The three practices are as follows:

i) Because officers are employed in the less physically demanding "staff" positions more often than NCMs, the officer CMRB assesses employability more flexibly.

ii) Because the officer General Specifications are so vague (as discussed above) in comparison with the NCM General Specifications, the officer CMRB has more "flexibility" in assessing an officer's suitability for GMD. Indeed, it expressed an unwillingness to recommend the imposition of career restrictions or release based on such vague criteria. ${ }^{115}$

iii) The officer CMRB focuses more on the member's ability to do the job that $\mathrm{s} / \mathrm{he}$ is currently doing than on the "global" responsibilities of the military occupation. By contrast, the NCM CMRB places greater emphasis on a member's flexibility of employment in all environments and ability to perform the GMD.

These three practices highlight the inflexibility of the GMD standard that is applied by the NCM CMRB. This was precisely the problem raised by the tribunal in the Levac $^{116}$ case when it noted that CWO Levac was a very senior member whose job was primarily supervisory and whose chances of being sent to sea seemed slim in any case. Although the NCM CMRB handles a much higher volume than the officer CMRB, it may still be significant that every case discussed in this article that arose through a CMRB release involved a non-commissioned member and not an officer.

The fact that the officer CMRB is able to apply the GMD standard flexibly, to focus on the member's actual job, and to make some assessment of the probability that $\mathrm{s} / \mathrm{he}$ will be called upon to fill the various roles described in the GMD shows that the same 
standard can be met by the NCM CMRB. Moreover, those tribunals that had the most difficulty in accepting the concept of universality of service seemed to focus on this same point. ${ }^{117}$ They were unable to accept that the individual in question would realistically be called upon to do the type of duty being described. In my view, this does not so much undermine the concept of universality of service, as it underscores the need to apply it realistically and in the context of a particular individual's probable employment.

\section{F. SAME STANDARD FOR ALL RANKS (AND ALL AGES)}

The officer's General Specification, in addition to being vague, also fails to make any distinction based on the rank of the individual, although some requirements do refer to the member's "normal duties". For example, the level of physical fitness must be sufficient to complete "normal duties" (as well as meet any emergency), and officers must be able to perform their "primary military duty" in the chemical warfare suit. ${ }^{118}$ But the question arises: should the same level of ability be required for all ranks? Technically, under this Specification, the same level of fire-fighting ability is required of the most junior officer and the most senior General. ${ }^{119}$ In practice, as discussed above, the officer CMRB discounts such requirements based on a realistic assessment of the officer's probability of being called upon to perform the duty should a crisis arise. It should not be forgotten that some senior officers do face front-line conditions; for example, Commodore Summers, who commanded the Persian Gulf expeditionary force, undertook the same training for and risks of chemical attack as other service members in the Gulf, and the commander of the Special Service Force in Petawawa is a qualified and active parachutist, just as are his troops. But the question remains: how likely is it, in any form of crisis, that very many of our senior officers will have to meet these challenges?

The NCM General Specification does distinguish in its task descriptions on the basis of rank, but it does so generally by requiring a more detailed knowledge at higher ranks or an ability to supervise the activity as well as perform it. For example, with regard to field survival tasks, every Private must be able to perform the tasks with a "detailed" knowledge and a "semi-skilled" ability, while all Master Corporals and more senior ranks must be able both to perform and to supervise the activities at these levels. ${ }^{120}$ With regard to Base Defence Force duties, which often arise in evidence before tribunals, the Specification requires a "basic" knowledge and ability in all NCMs from Privates to Chief Warrant Officers. ${ }^{121}$ Therefore, even though the NCM General Specification distinguishes on the basis of rank, it does not seem to address (or allow any flexibility in respect of) whether an individual is likely to have to perform these tasks.

Examples of such cases are DeJager, supra note 64; Robinson, supra note 73; and Levac, supra note 42.

118 Classification Structure, supra note 28 at 2-2-2 and 2-3-11.

$119 \quad$ Ibid. at 2-3-19.

120 NCM Trade Structure, supra note 30 at 3A-15.

$121 \quad$ Ibid. at 3A-16. 
It seems clear that with increasing seniority many service members will become less likely to be involved in the most physically demanding activities. Of course, I should hasten to add that, for other members, the likelihood will not diminish; for example the most senior person serving at sea on a ship has a realistic (although perhaps not identical) possibility of having to fight a fire as the most junior member. The point is that the requirement requires an individual assessment, and based on the experience of the officer CMRB, it seems to be susceptible to individual assessment.

I should add two caveats to this proposal for more flexible assessment based on the fact some members are less likely to be placed in situations where they will have to perform specific physically demanding roles. First, one can visualize a group of senior, perhaps soon-to-retire, members filling "staff" jobs in various large bases and at NDHQ. The problem is that, while this accommodates the need for individual assessment, it ignores the question of leadership by example and the desirability for military cohesiveness. Put at its simplest, it is an anathema to the military ethos to suggest that a category of physically incapable senior Generals and senior NCMs can run things from the headquarters while the "real" soldiers do the demanding jobs in the field. Leadership by example is central to morale in the Armed Forces and to an effective military organization. Therefore, while an individual assessment of the likelihood of future involvement in GMD is relevant and useful, the exceptions to the general rule must be limited to a small proportion of the group who remain "soldiers first" and who can perform the GMD in a crisis, regardless of their present job. The tribunal in Boivin expressed the issue as follows:

While it may appear a simple matter to accommodate one, two or an indefinite number of individuals who fall below the standards, the question arises of how far the Armed Forces should go without compromising their efficiency. ${ }^{122}$

Second, while I support the relevance of assessing an individual's likelihood of performing specific duties should an emergency occur, I would like to distinguish this from assessing the probabilities that a given emergency will arise. The chances of Canada being involved in another war, or of a fire in a given ship, or of an attack on a given base may all be small. But a correct and adequate response is critical if these things do occur, and the possibility of their occurrence is at the heart of the rationale for Canada even having an Armed Force. A useful illustration can be found in the Seguin case. ${ }^{123}$ The chance of a terrorist attack at a given airport is very small, but it is a real possibility and an adequate response to such an attack is critical. On the other hand, if an attack does occur at an airport, then it is highly likely that each static guard at the airport will be involved. So, in the Armed Forces, it is reasonable to assess whether a given member of the CF is likely to be involved in a given type of crisis should it occur. 


\section{G. TREATING EXISTING EMPLOYEES DIFFERENTLY}

In this next section I would like to examine briefly the ways in which serving members of the Forces are treated differently from applicants in terms of medical standards, and the defensibility of doing so.

\section{Higher Medical Enrolment Standard Than Military Occupation Standard}

As mentioned above, the Common Minimum Enrolment Standard (CMES) is: V4 CV3 - H2 - G2 - O2 - A5. This means that regardless of the military occupation for which $\mathrm{s} / \mathrm{he}$ applies, an applicant cannot enrol in the CF unless $\mathrm{s} / \mathrm{he}$ meets this standard. In some cases a military occupation medical standard will be higher in some respect, in which case it will govern. The CMES applies to a recruit until s/he completes recruit training, then the military occupation's medical standard becomes effective. ${ }^{124}$ There is an explicit exception to this CMES. Where an applicant possesses special qualifications such as experience and skill in a trade or professional qualifications, the CMES can be waived and the normal military occupation medical standards, as shown in Annex A, will apply. There is no express exception made for the re-enrolment of service members with prior service, but the general rule is that if they are re-enroled within five years of their release date, they will be exempted from recruit training and the CMES. ${ }^{125}$ Skilled applicants without prior service may receive a waiver if the individual is judged capable of fulfilling all of the relevant duties and possesses a special skill much needed by the CF. According to the CF Medical Standard, the military occupation standard must be met in such a case, rather than the CMES, but I came across some unconfirmed (anecdotal) evidence that even this standard has been waived in at least one case. ${ }^{126}$ Indeed it is not hard to imagine that in a major crisis the entry standards could be relaxed across the board to ensure that Canada could mobilize to meet the challenge.

The medical waiver system was discussed in Dunmall v. CAF. ${ }^{127}$ In that case, a dental hygienist was released from the Regular Force because of a mild permanent disability. Eleven years later she applied to join the Reserve Force but was refused. In obiter, the tribunal praised the medical waiver system and stated that it should have been used to make an exception for the complainant because of the distinct terms of service under which she would have joined. In their view, the waiver system can provide the flexibility necessary to avoid, in the words of the Brossard ${ }^{128}$ case, placing an undue burden on anyone.

Medical Standards, supra note 8 at 3-1. To be entirely accurate, this describes the situation for officers but it is not entirely clear when the transition occurs for NCMs. It is proposed to bring this into conformity with the officer system. See Medical Process, supra note 27 at Annex B at 2. Medical Process, ibid. at Annex B at 2.

126 I was informed that, because of a special need, a physician was enrolled although he only had vision in one eye and could not meet either the CMES or the classification medical standard. 
However, the general rule is that a minimum enrolment standard applies which, in the case of many military occupations, exceeds the standard required of serving members. The rationale for the distinct CMES is set out in the Medical Manual as follows:

1. A certain standard is required of recruits so that they may be eligible for the widest selection of military occupations. To take the highest common denominator would be too restrictive and to take the lowest common denominator would be to accept too many recruits with employment limitations. As it is the aim to keep the medical standards of the Canadian Forces high and it is inevitable that the category of many serving personnel will be lowered during their career, it is required that we demand a high medical standard of our recruits. ${ }^{129}$

The case law generally supports such distinctions between applicants and currently employed personnel. In Parent v. Department of National Defence, ${ }^{130}$ it was alleged that the complainant was refused employment because of physical disability. The tribunal concluded that he was in fact unable to do the job because of his condition. It also noted that the department had a policy of retaining personnel with medical handicaps even though it would not hire a person who applied with such a handicap. ${ }^{131}$ The tribunal ruled that this distinction was not a discriminatory policy. Galbraith v. Canadian Armed Forces ${ }^{132}$ involved a refusal to enrol a man with a continent ileostomy. While this was not the primary issue before them, the tribunal accepted an explanation substantially similar to that in the CF Medical Manual for a difference in treatment between applicants and serving members.

Seguin v. Royal Canadian Mounted Police dealt with the RCMP's uncorrected vision standard for static guards. With respect to the difference in standards for new recruits as opposed to serving members, the tribunal said:

\footnotetext{
Physical deterioration being a natural process with age, it was shown that the RCMP has an administrative process in place to deal with existing members who fail physical re-examinations.... [T] he RCMP is a paternalistic organization and ... an effort is made to relocate such members within the organization rather than dismiss them. Each case is dealt with on its own merits and numerous factors may be considered.
}

I find this to be a practical and reasonable approach to be taken. ${ }^{133}$

Notably, this approach sounds very similar to the CMRB, where an effort is made to evaluate the employability of serving members. The evaluation is made on an individual basis, and the process also encompasses a wide range of factors.

Medical Standards, supra note 8 at 3-1.

(1980), 1 C.H.R.R. D/121.

Ibid. at D/122, para. 1062.

Supra note 6 at D/6525, para. 45864.

Supra note 78 at D/6006, paras. $43386-87$. 
However, the rationale in the Seguin case does suggest one anomaly in the CF Medical System. If the purpose of the higher entry standard is to compensate for physical deterioration over the course of the individual's career, then one must ask why there is a common entry standard even though the military occupations require different profiles. That is, why not have a higher entry standard for the more physically demanding military occupations? The G2-O2 entry standard provides some leeway for the more sedentary trades, but none for the more physically demanding combat arms trades. This seems to correspond with the relatively high CMRB release rate for the combat arms trades which was discussed above. There is a partial answer in the rationale quoted above from the Medical Manual: it might be unrealistic to demand too high a standard. However, it does not fully answer the anomaly that the entry standard provides no margin for deterioration in some military occupations and a significant margin in others. There is insufficient data to suggest whether a higher entry standard for the more demanding military occupations is impractical or on the other hand, unnecessary. It may be that the gradation scale is simply too clumsy to allow for a small but practical margin at the upper end, since the next step up, G1-O1, is both unnecessary and too demanding an entry standard for even the combat arms trades. It may also be that the unstated reason for the common G2-02 entry standard is to meet the rigours of recruit training.

Another approach to this anomaly would be to ensure that the medical standards and Specifications are applied more flexibly in the context of evaluating the likelihood that an individual will have to perform a given role. This would provide some margin for deterioration in itself, given the increasingly supervisory roles a service member assumes with higher ranks.

\section{Retention Below Military Occupation Standard}

Assuming for the moment that the Military Occupation, Environmental and General Specifications as well as the medical standards that are derived from them are defensible as BFORs, then the CMRB process represents two things. First, because it reviews the raw data from the individual's medical file, it is a check on the accuracy of the assessments that have been made about the individual in terms of the Specifications and medical standards. It should ensure consistency across the many doctors and Commanding Officers who provide input and recommendations from the local level, as well as fairness by weeding out any unsupported negative assessments that might arise from local personality conflicts. Second, the CMRB represents an attempt to accommodate a failure to meet a BFOR by assessing whether the individual can, notwithstanding a medical disability, still perform a sufficient preponderance of the roles in his/her military occupation or can efficiently be retrained and employed in another trade.

As was decided in the Alberta Dairy Pool case, this accommodation is not a legal requirement once a BFOR is established, but it is pursued by the CF for at least two reasons. Teamwork and the protection of "one's own" are integral parts of the military ethos and are also essential to the development of esprit de corps. The attempt to retain service members is part of this approach. In addition, the retention of experienced, 
trained and skilled service members makes good economic sense and so is pursued out of genuine self-interest.

But the accommodation of medical deficiencies is a double-edged sword. Apart from providing these important benefits, it also represents a weakness in the BFOR defence. For if a certain number of personnel who fall below the standard can be retained, then, is the standard really necessary? Or if it is necessary, apart from a small percentage, why is a certain, apparently arbitrary percentage the maximum?

At the end of 1989 there were 18,733 officers in the Regular Force, 1.68 percent of whom had a permanent medical category with a "G" or "O" factor below the relevant military occupation minimum. Of $68,719 \mathrm{NCMs}, 1.8$ percent were similarly below the "G" or "O" standard. ${ }^{134}$ If the other medical factors are included, then the percentage rises to 9.5 percent for officers and 5.3 percent for NCMs. Most of these additional cases below minimum standard involve vision or hearing. ${ }^{135}$

It is difficult to defend any particular percentage of unfit members as being the maximum that is acceptable. Any particular cut-off point is bound to be arbitrary. However, in setting a particular objective standard, the tribunals have generally required only that it fall within a "reasonable range". ${ }^{136}$ In the case of the percentages of unfit service members, it may be that they result, not from any effort to achieve a given level, but merely from hundreds of individual CMRB decisions. Each decision focuses on the employability of the individual, the number of unfit persons in that trade, and the number of unfit persons that the trade can bear without excessive loss of efficiency or flexibility. This level should vary between the trades depending on the type of wartime, peace-time, and crisis roles that military occupation will fill, as well as the probability that its members will perform various GMDs.

This issue of finding a balance between retention of personnel with limited employability and adhering to the medical standards was addressed in a letter written by the DND Assistant Deputy Minister of Personnel in April $1990 .{ }^{137}$ In addressing a natural desire to retain personnel whenever possible, he commented on the abovementioned percentages of unfit personnel:

The retention of these people must be carefully balanced against our primary task as a military force bearing arms, if required, and for that reason we cannot afford to further increase these percentages. $^{138}$

With respect to reclassifying medically unfit personnel to the support trades, he said:

Medical Process, supra note 27 at Annex C, Appendix 7.

Ibid. at Annex C, at 3.

For example, see Seguin, supra note 78 at D/6011, para. 43408.

Medical Process, supra note 27 at Annex C, Appendix 12.

Ibid. at 2. 
[A]lthough we are in a peacetime mode the various $U N$ taskings require a healthy flexible force. Our contributions so far have been weighted towards the support trades, which again mitigates against reclassifying people into these trades who either do not meet the minimum medical standards or are highly restricted in where and how they can be employed. ${ }^{139}$

The retention of "unfit" personnel, when possible, is seen by many in the Armed Forces as a desirable practice in terms of "taking care of their own". However, the ability to do so is limited by a need for operational readiness and, ironically, by the fact that human rights challenges will pick up on any inconsistencies, demanding equivalent treatment for all similar cases.

The accommodation of serving personnel who fall below the medical standard for their military occupation is also a process of exhausting the alternative employment possibilities which equity demands. In the end, each decision not to retain or to reclassify a member will have to be defended, not on the basis of a global percentage, but on the incompatibility of each individual medical condition with the demands of the military occupation or of the GMD.

\section{CONCLUSIONS}

\section{A. GENERAL}

Almost all of the cases which have challenged CF employment decisions based on human rights grounds have involved clashing visions of what the military is all about. Human rights advocates often see the CF as an inflexible and overly conservative institution clinging to out-dated standards and stereotypes. It is natural to question why military policies have not, apparently, been brought into conformity with current legal standards and societal norms dealing with the disabled.

Military policy makers know that, in terms of its roles and constraints, the Canadian military organization is unique among Canada's employers. The closest parallels are found in fire fighting and police forces which must also provide immediate response to emergency situations. However, there are significant differences between the civil emergency forces and the CF. The primary role of the CF is to provide an armed force that can, with our allies, deter aggression contrary to Canada's interests and engage and defeat such an aggressor should it become necessary. This role would subsume strategic deterrence, conventional defence, protection of sovereignty, and peacekeeping. Below it lie the other roles such as civil responsibilities in Canada (Aid of the Civil Power, penitentiary reinforcement, etc.), humanitarian assistance, and arms control verification.

What distinguishes this primary role even from that of the civil emergency forces is that it arises so infrequently and so unpredictably. When it does arise, however, the response is critical, certainly in terms of human life and suffering, and perhaps in terms of national survival. What it has in common with the civil emergency forces is that 
almost by definition, the nature of the emergency will be unpredictable, as will the type and level of response needed.

The characteristics of these roles have lead nations over the centuries to develop military forces that are comprised of, in T.C. Willett's view, a large body of physically fit, disciplined individuals, loyal to the state and able to act in unison, initially without question and at short notice. They are highly mobile on land and sea and in the air, despite natural obstacles, and are able to function in extremes of climate away from fixed bases. They can operate in the field (independently) from their own resources, and under maximum stress for prolonged periods. ${ }^{140}$

The seed for the clash in visions is found in the fact that the actual need to perform these roles occurs so infrequently and unpredictably. The other problem is that the majority of responses required for emergencies fall well below a maximal response. We may send a battalion of soldiers (with administrative, logistic and communications support) to Cyprus, Namibia or Yugoslavia for peacekeeping purposes but, even in this confrontational and dangerous role, very little actual conflict occurs. The fact that the need for a maximal response occurs so infrequently means that we inevitably settle into a peacetime or "garrison" mode.

Then the question quite naturally and reasonably arises: are these standards necessary? The answer, I believe, is found in the role of the CF, as it is defined from time to time by the Canadian government. At present it is defined, quite logically, in the terms I have described above, and so the answer to the question is that yes, a high standard of medical fitness is justified for Canadian service members, with appropriate variations for the peacetime and wartime responsibilities of the individuals.

The concept of reasonable accommodation has received considerable attention over the past few years. The test itself was clearly enunciated in the Etobicoke ${ }^{141}$ case, and its relationship to the BFOR should have been settled by Alberta Dairy Pool..$^{142}$ Some tribunals have continued to suggest, notwithstanding Alberta Dairy Pool, that reasonable accommodation must be proved in addition to a BFOR in order to defend a case of direct discrimination. ${ }^{143}$ In my view, this is clearly wrong. The majority in Alberta Dairy Pool went to great lengths to clarify that this was not so and that cases of direct discrimination involving BFOR defences focus on the job and the group, but not on the individual. On the other hand, the Cremona ${ }^{144}$ case has clarified that the

T.C. Willeth, "Military Roles in the 1970 " in R.B. Byers \& S.G. Colin, eds., Canadian Military Professionalism: the search for identity (Toronto: Canadian Institute of International Affairs, 1973) 49 at 52-56. I have selected from Willett's list of unique characteristics those which are relevant to medical selection standards.

Supra note 44.

See Levac v. CAF (1992), 15 C.H.R.R. D/175 at D/194, where the tribunal, after reviewing Alberta Dairy Pool, imposed a requirement to accommodate even though the discrimination was clearly "direct". On review, the Federal Court of Appeal characterized this apparent error as "superfluous", supra note 42.

Supra note 58. 
establishment of the BFOR may require proof that it is not practical to test individually for employee failure.

Another current issue is the question of risk: whether an employee must be allowed to assume risk of injury to him or herself, and the degree of risk to other employees and the public sufficient to support a BFOR. In my view, the question was settled by Etobicoke, ${ }^{145}$ Bhinder ${ }^{146}$ and Mahon ${ }^{147}$ (and not over-turned by Alberta Dairy Pool): evidence of a "real risk" as opposed to a speculative risk, particularly to the public, is sufficient to substantiate a BFOR. Similarly, an employer is not required by the Canadian Human Rights Act $^{148}$ to place or leave an employee in a situation where $\mathrm{s} /$ he risks more than a trivial injury.

\section{B. THE CANADIAN FORCES MEDICAL SYSTEM}

The CF has created a highly complex and structured personnel system. Studies of the various roles to be performed have led to a division of labour into more than a hundred military occupations whose skills, knowledge levels and training are spelled out by the Specifications. Every service member is governed by three such Specifications: one that is unique to his or her military occupation, one that is unique to the Environment in which $\mathrm{s} / \mathrm{he}$ is employed, and one which is General to all service members.

The medical standards are described in terms of six factors, including geographical and occupational limitations, with grading systems for each factor. A medical analysis of the Specifications has led to the establishment of minimum medical standards for each military occupation and for entry into the Armed Forces. While these minimum medical standards provide an efficient management tool for categorization, the fact remains that important employment decisions must still be made based on a more individual review of a particular member's medical condition, the requirements of the job, and the requirements of the Armed Forces. This individual review is the function of the Career Medical Review Board.

My review of the military medical system has shown that several of its aspects, while different from the mainstream of employment practices, can withstand legal scrutiny and have been accepted by the human rights tribunals. On the other hand, a number of areas invite reform.

Of the areas that have achieved judicial acceptance and have withstood scrutiny, the concept of "universality of service" is most central to the military system. It demands that whatever a service member's day-to-day job may entail, s/he remains a "soldier first" and must always be capable of performing a core of military duties. A number of tribunal cases have explicitly accepted this concept, and even those that have chosen not to apply it have done so because the evidence did not support the relevance of a 
particular duty, rather than because the concept of universality was ill-founded. The "soldier first" concept is rooted in the need for a military force to attain a maximum level of flexibility and readiness to perform roles that will not crystallize until a crisis arrives. Such a crisis requires a rapid response, and while further recruiting and retraining may be possible at a national level, the military force in-being must be able to respond immediately.

Another way to view the responsibilities of a soldier in a support role is to compare them with the responsibilities of an equivalent civilian position. As the Gaetz ${ }^{149}$ case noted, a military supply technician, unlike the civilian counterpart, is liable to be posted to (and integrated into) a combat unit, and to be called upon to defend his static base as a part of the Base Defence Force. Therefore, to keep this issue in perspective, it is always useful to ask why a particular position is filled by a military service member rather than a civilian employee.

The infrequency and unpredictability of crises requiring military response lead, in some circles, to a complacency about the need to maintain a military capability. ${ }^{150}$ The case law is clear ${ }^{151}$ that as long as such events remain a real risk, then because an adequate response is so critical, the standards which permit that adequate response are justified.

This review has revealed a number of weaknesses in the CF medical and personnel system that should be addressed and reformed. It is acknowledged that these weaknesses may already be addressed by informal practices that are perpetuated by the ubiquitous "corporate memory", however, this is no substitute for a well thought-out and promulgated policy. The weaknesses are summarized as follows:

a) An interesting practice that probably touches any large organization is that of treating existing employees differently from applicants. The tribunals have noted that it is driven partly by loyalty and partly by the efficiency of retaining a valuable, experienced and skilled employee. They have generally acknowledged such practices as acceptable, although it has not been the central issue of any of the cases reviewed. It is likely that the practice would reach its limit where it was used to exclude an applicant on some invidious ground or where the preference shown for the existing employee could not be justified on objective grounds related to job performance. The CMRB system regularly authorizes the retention of service members that have fallen below military occupation medical standards, let alone the CMES. The test of "employability" is relevant to the criteria of skill and experience, but there is no attempt to compare the relative merits of the skilled (but below medical standard) member with a generic unskilled applicant who meets the medical standards. While this theoretically seems like an available challenge to CMRB decisions, it would be difficult to launch in practice because

150 Although the past few years, with the Oka and Persian Gulf crises, have been remarkable exceptions.

151 See Seguin, supra note 78. 
of the difficulty of an applicant either obtaining adequate information or of demonstrating a useful comparison with any particular CMRB decision. Nonetheless, statistical evidence, such as that discussed above, could provide support to such a challenge. To address this, the CMRB decision-making process should be reviewed to ensure that the retention of serving members who fall below the stated medical standards is objectively related to off-setting skill and experience levels.

b) While the consequences of failing to meet Military Occupation or General Specifications are well understood, the same does not seem to be true for the Environmental Specification. A failure to meet the Military Occupation Specification clearly reveals a weakness with respect to capability for that trade, and a failure to meet the General Specification shows the same for a capability to perform as a service member generally, but the Environmental Specification is quite different. A failure to meet only the Environmental Specification implies that the member can quite competently perform both the trade and the soldierly duties, but simply has limited employability in one of the Environments. This poses something of a problem for the Forces since "unification" has attempted to remove environmental distinctions in so far as they affect employability, particularly of the "green trades". I have suggested that a distinction should be made depending on whether the failure is immutable or not; however, in either case it does not seem justified to discriminate against the individual in terms of career limitations. It is current practice to deal with failures of the Environmental Specification by transfer, in cases of an immutable problem, or extra training in other cases. While this seems acceptable, it is not clear that the latter cases leave no impact on the individual's career, and there is no policy statement on the matter. It is recommended that the consequences of failing to meet the Environmental Specification be reviewed and a policy be promulgated.

c) Decisions of the CMRB have great impact on the life of the member involved. It is crucial that they be objective, rational and consistent. One weakness in this decision-making process is the "percentage of employability". The guidelines that determine the cut-off points for disposition of the cases are not justifiable without some underlying, preferably scientific, rationale. It is not clear why these cut-off points are appropriate, nor why the same levels are appropriate for every military occupation. Without further justification, the system is vulnerable to accusations of administrative convenience and arbitrariness. It is recommended that the guidelines and cut-off points for CMRB decisions be reviewed and founded on an articulated, defensible rationale. It is also recommended that CMRB procedures adhere to the general principles of administrative fairness.

d) The rationale for having a higher enrolment standard than is required for most military occupations is founded, according to the relevant manual, on the inevitable lowering of medical standards over a person's career. While the cases generally accept such distinctions, the CF policy runs into difficulty because the enrolment standard is uniform, while the military occupation standards that the recruit must meet after recruit training vary. So, there is a margin for declining 
fitness for some military occupations and none for others. The rationale for the CMES should be reviewed.

e) The difference in release rates for the officer CMRB and the NCM CMRB reveal a significant difference in procedure and philosophy between the two boards. The officer CMRB focuses more on the member's current job and assesses the likelihood that $\mathrm{s} / \mathrm{he}$ will be required to perform the various GMDs. This is taken into account when assessing the member's future employability. The NCM CMRB is much less flexible regarding the requirement to be able to fulfill the GMDs. In my view, the officer CMRB's approach, although flexible, is consistent with the concept of universality of service. The premise remains that every service member must have the ability to perform the core of military duties. However, there will arise exceptional cases in which a given member is unlikely to have to perform specific duties even if a crisis arises. A good example was the Levac $^{152}$ case in which a change in personnel policy created an abnormally large group of senior marine engineers who, simply because their numbers significantly exceeded the available seagoing positions, were unlikely to be sent to sea. The concept of universality should be flexible enough to accommodate such exceptions. To remain inflexible in the face of such facts costs credibility. Therefore, the approaches of the officer and NCM CMRBs should be harmonized, and the application of the concept of "universality of service" should be flexible concerning exceptional circumstances in which an individual is unlikely to be called upon for specific GMDs, even in the event of a crisis.

f) The concept of "universality" and being a "soldier first" depend very heavily on the GMDs described for officers and non-commissioned members in the General Specifications. Yet these GMDs are described in the vaguest of terms, particularly for the officers. They seem to be no more than impressionistic, a fatal term in human rights law, and this critically undermines the credibility of the medical standards derived from them. It is essential that the description of the GMDs be revised, clarified and made more specific. At the same time these standards will only be credible if they are made a routine part of the training of all service members.

As a closing note I should re-emphasize my conclusion that membership in the Armed Forces has no exact civilian employment equivalent. One of the key differences is captured by the phrase "soldier first", which is used by human rights tribunals to distinguish between routine tasks and the capability of meeting ill-defined crises. It is all too easy to forget that the day-to-day tasks represent only a part of the commitment. It is the essence of peace-time military life to prepare to serve one's country in a crisis, hoping that it never comes. 


\section{ANNEXES}

ANNEX A: MILITARY OCCUPATIONS OF THE CANADIAN FORCES (including minimum medical standards) ${ }^{153}$

\begin{tabular}{|c|c|c|c|c|c|c|c|}
\hline & OFFICERS & & & & & & \\
\hline $\begin{array}{l}\text { OCC. } \\
\text { CODE }\end{array}$ & OCCUPATION & V & CV & $\mathbf{H}$ & G & $\mathrm{O}$ & A \\
\hline 21 & Armour & 3 & 3 & 3 & 2 & 2 & 5 \\
\hline 22 & Artillery & 3 & 3 & 2 & 2 & 2 & 5 \\
\hline 23 & Infantry & 3 & 3 & 3 & 2 & 2 & 5 \\
\hline 31 & Air Navigator & 3 & 2 & 2 & 2 & 2 & 2 \\
\hline 32 & Pilot & 1 & 2 & 2 & 2 & 2 & 1 \\
\hline 41 & Aerospace Engineer & 4 & 2 & 3 & 3 & 3 & 5 \\
\hline 42 & $\begin{array}{l}\text { Communications and Electronics } \\
\text { Engineer }\end{array}$ & 4 & 3 & 3 & 2 & 2 & 5 \\
\hline 43 & $\begin{array}{l}\text { Land Electrical and Mechanical } \\
\text { Engineer }\end{array}$ & 4 & 3 & 3 & 2 & 2 & 5 \\
\hline 44 & Maritime Engineer & 3 & 2 & 3 & 2 & 2 & 5 \\
\hline 45 & Military Engineering & 3 & 3 & 3 & 2 & 2 & 5 \\
\hline 51 & Dentist & 4 & 3 & 3 & 3 & 3 & 5 \\
\hline 52 & Dental Associate & 4 & 3 & 3 & 3 & 3 & 5 \\
\hline 53 & Physical Education \& Recreation & 4 & 3 & 3 & 3 & 3 & 5 \\
\hline 54 & Pharmacist & 4 & 3 & 3 & 3 & 3 & 5 \\
\hline 55 & Medical (Doctor) & 4 & 3 & 3 & 3 & 3 & 5 \\
\hline 56 & Medical Associate & 4 & 3 & 3 & 3 & 3 & 5 \\
\hline 57 & Nurse & 4 & 3 & 3 & 3 & 3 & 5 \\
\hline 58 & Social Work & 4 & 3 & 3 & 3 & 3 & 5 \\
\hline 59 & Pastoral Associate & 4 & 3 & 3 & 3 & 3 & 5 \\
\hline
\end{tabular}

153 Source: Annex B to CFAO (Canadian Forces Administrative Order) 34-30, Medical Standards for the Canadian Forces. 


\begin{tabular}{|c|c|c|c|c|c|c|c|}
\hline & OFFICERS & & & & & & \\
\hline $\begin{array}{l}\text { OCC. } \\
\text { CODE }\end{array}$ & OCCUPATION & V & $\mathrm{CV}$ & $\mathrm{H}$ & G & 0 & A \\
\hline 61 & Chaplain Protestant & 4 & 3 & 3 & 3 & 3 & 5 \\
\hline 62 & Chaplain Roman Catholic & 4 & 3 & 3 & 3 & 3 & 5 \\
\hline 63 & Air Traffic Control & 3 & 2 & 2 & 3 & 3 & 4 \\
\hline 64 & Air Weapons Control & 3 & 2 & 2 & 3 & 3 & 4 \\
\hline 65 & Flight Engineer & 3 & 2 & 2 & 2 & 2 & 2 \\
\hline 66 & Public Affairs & 4 & 3 & 3 & 3 & 3 & 5 \\
\hline 67 & Legal & 4 & 3 & 3 & 3 & 3 & 5 \\
\hline 68 & Personnel Administration & 4 & 3 & 3 & 3 & 3 & 5 \\
\hline 69 & Logistics & 4 & 3 & 3 & 3 & 3 & 5 \\
\hline 71 & Maritime Surface and Sub-Surface & 3 & 2 & 2 & 2 & 2 & 5 \\
\hline 72 & Personnel Selection & 4 & 3 & 3 & 3 & 3 & 5 \\
\hline 73 & Meteorology & 4 & 3 & 3 & 3 & 3 & 5 \\
\hline 74 & Training Development & 4 & 3 & 3 & 3 & 3 & 5 \\
\hline 75 & Music & 4 & 3 & 3 & 3 & 3 & 5 \\
\hline 76 & Postal & 4 & 3 & 3 & 3 & 3 & 5 \\
\hline 81 & Security & 4 & 2 & 3 & 3 & 3 & 5 \\
\hline 82 & Intelligence & 4 & 2 & 3 & 3 & 3 & 5 \\
\hline R86 & Naval Control of Shipping & 3 & 2 & 2 & 2 & 2 & 5 \\
\hline & General Officers & 4 & 3 & 3 & 3 & 3 & $\begin{array}{l}5 \\
\text { or } \\
7\end{array}$ \\
\hline & NON-COMMISSIONED MEMBERS & & & & & & \\
\hline CODE & OCCUPATION & V & $\mathrm{CV}$ & $\mathbf{H}$ & G & $\mathrm{O}$ & A \\
\hline 011 & Crewman & 3 & 3 & 3 & 2 & 2 & 5 \\
\hline 021 & Artilleryman Field & 3 & 2 & 3 & 2 & 2 & 5 \\
\hline 022 & Artilleryman Air Defence & 3 & 2 & 3 & 2 & 2 & 5 \\
\hline
\end{tabular}




\begin{tabular}{|c|c|c|c|c|c|c|c|}
\hline & OFFICERS & & & & & & \\
\hline $\begin{array}{l}\text { OCC. } \\
\text { CODE }\end{array}$ & OCCUPATION & V & CV & $\mathbf{H}$ & G & $\mathbf{O}$ & $\mathbf{A}$ \\
\hline 031 & Infantryman & 3 & 3 & 3 & 2 & 2 & 5 \\
\hline 041 & Field Engineer & 3 & 2 & 3 & 2 & 2 & 5 \\
\hline 042 & Field Engineer Equipment Operator & 3 & 2 & 3 & 2 & 2 & 5 \\
\hline 052 & Lineman & 3 & 2 & 3 & 2 & 2 & 5 \\
\hline 065 & Naval Weapons Tech. & 3 & 2 & 3 & 2 & 2 & 5 \\
\hline 081 & Airborne Electronic Sensor & 3 & 2 & 2 & 2 & 2 & 2 \\
\hline 091 & Flight Engineer & 3 & 2 & 2 & 2 & 2 & 2 \\
\hline 111 & Intelligence Operator & 4 & 2 & 3 & 3 & 3 & 5 \\
\hline 121 & Meteorological Tech. & 4 & 2 & 3 & 3 & 3 & 5 \\
\hline 131 & Search \& Rescue Tech. & 2 & 2 & 2 & 2 & 2 & 4 \\
\hline 141 & Topographical Surveyor & 4 & 2 & 3 & 3 & 3 & 5 \\
\hline 151 & Map Reproduction Tech. & 4 & 2 & 3 & 3 & 3 & 5 \\
\hline 161 & Air Traffic Controller & 3 & 2 & 2 & 3 & 3 & 4 \\
\hline 162 & Air Traffic Control Asst. & 3 & 2 & 2 & 3 & 3 & 4 \\
\hline 171 & Air Defence Tech. & 2 & 2 & 3 & 3 & 3 & 5 \\
\hline 181 & Boatswain & 3 & 2 & 3 & 2 & 2 & 5 \\
\hline 191 & Oceanographic Operator & 4 & 2 & 2 & 2 & 2 & 5 \\
\hline 211 & Radio Operator & 4 & 2 & 3 & 2 & 2 & 5 \\
\hline 212 & Teletype Operator & 4 & 3 & 3 & 3 & 3 & 5 \\
\hline R214 & Radio \& Teletype Operator & 4 & 2 & 3 & 2 & 2 & 5 \\
\hline 221 & Radio Tech. & 4 & 2 & 2 & 3 & 3 & 5 \\
\hline 222 & Terminal Equipment Tech. & 4 & 2 & 2 & 3 & 3 & 5 \\
\hline 223 & Teletype \& Cypher Tech. & 4 & 2 & 3 & 3 & 3 & 5 \\
\hline 224 & Communications Tech. & 4 & 2 & 3 & 3 & 3 & 5 \\
\hline 231 & Radar Tech. & 4 & 2 & 3 & 3 & 3 & 5 \\
\hline
\end{tabular}




\begin{tabular}{||l|l|l|l|l|l|l|l||}
\hline \hline & \multicolumn{1}{|c|}{ OFFICERS } & & & & & & \\
\hline $\begin{array}{l}\text { OCC. } \\
\text { CODE }\end{array}$ & OCCUPATION & V & CV & H & G & O & A \\
\hline \hline 262 & Naval Signalman & 3 & 2 & 2 & 2 & 2 & 5 \\
\hline R263 & Shipping Control Operator & 3 & 2 & 2 & 2 & 2 & 5 \\
\hline 273 & Naval Acoustics Operator & 3 & 2 & 2 & 2 & 2 & 5 \\
\hline 274 & Naval Radio Operator & 4 & 2 & 2 & 2 & 2 & 5 \\
\hline 275 & Naval Combat Information Operator & 3 & 2 & 2 & 2 & 2 & 5 \\
\hline 276 & Naval Electronic Sensor Operator & 3 & 2 & 2 & 2 & 2 & 5 \\
\hline 283 & Naval Electronic Tech. (Acoustics) & 3 & 2 & 2 & 2 & 2 & 5 \\
\hline 284 & $\begin{array}{l}\text { Naval Electronic Tech. } \\
\text { (Communications) }\end{array}$ & 3 & 2 & 2 & 2 & 2 & 5 \\
\hline 285 & $\begin{array}{l}\text { Naval Electronic Tech. } \\
\text { (Tactical) }\end{array}$ & 3 & 2 & 2 & 2 & 2 & 5 \\
\hline 286 & $\begin{array}{l}\text { Naval Electronic Tech. } \\
\text { (Systems) }\end{array}$ & 3 & 2 & 3 & 2 & 2 & 5 \\
\hline 291 & Communications Research & 4 & 3 & 2 & 3 & 3 & 5 \\
\hline 312 & Marine Engineering Mechanic & 4 & 2 & 3 & 2 & 2 & 5 \\
\hline 313 & Marine Engineering Tech. & 4 & 2 & 3 & 2 & 2 & 5 \\
\hline 314 & Marine Engineering Artificer & 4 & 2 & 3 & 2 & 2 & 5 \\
\hline 321 & Hull Tech. & 4 & 2 & 3 & 2 & 2 & 5 \\
\hline 331 & Electrical Tech. & 2 & 2 & 2 & 2 & 2 & 5 \\
\hline 331 & Marine Electrician & 2 & 2 & 2 & 2 & 2 & 5 \\
\hline 341 & Clearance Diver & 4 & 2 & 3 & 2 & 2 & 5 \\
\hline 342 & Clearance Diver Tech. & 3 & 2 & 2 & 5 \\
\hline 411 & Vehicle Tech. & Weapons Tech. Land & 3 & 2 & 2 & 5 \\
\hline 421 & Electro-Mechanical Tech. & & 2 & 2 & 2 & 5 \\
\hline 431 & Fire Control Tech. (Electronic) & & & & & 5 \\
\hline 432 & & & 2 & 2 & 5 \\
\hline
\end{tabular}




\begin{tabular}{|c|c|c|c|c|c|c|c|}
\hline & OFFICERS & & & & & & \\
\hline $\begin{array}{l}\text { OCC. } \\
\text { CODE }\end{array}$ & OCCUPATION & v & $\mathrm{CV}$ & $\mathrm{H}$ & $\mathbf{G}$ & $\mathrm{O}$ & A \\
\hline 433 & Fire Control Tech. (Optronic) & 4 & 2 & 3 & 2 & 2 & 5 \\
\hline 435 & Fire Control System Tech. (Land) & 4 & 2 & 3 & 2 & 2 & 5 \\
\hline 441 & Materials Tech. & 4 & 2 & 3 & 2 & 2 & 5 \\
\hline 511 & Aeroengine Tech. & 4 & 2 & 3 & 3 & 3 & 5 \\
\hline 512 & Air Frame Tech. & 4 & 2 & 3 & 3 & 3 & 5 \\
\hline 513 & Aviation Tech. & 4 & 2 & 3 & 3 & 3 & 5 \\
\hline 521 & Integral Systems Tech. & 4 & 2 & 3 & 3 & 3 & 5 \\
\hline 524 & $\begin{array}{l}\text { Communications and Radar Systems } \\
\text { Tech. }\end{array}$ & 4 & 2 & 2 & 3 & 3 & 5 \\
\hline 525 & Avionics Tech. & 4 & 2 & 3 & 3 & 3 & 5 \\
\hline 531 & Safety Systems Tech. & 4 & 2 & 3 & 3 & 3 & 5 \\
\hline 541 & Photographic Tech. & 4 & 1 & 3 & 3 & 3 & 5 \\
\hline 551 & Instrument Electrical Tech. & 4 & 2 & 3 & 3 & 3 & 5 \\
\hline 561 & Metals Tech. & 4 & 2 & 3 & 3 & 3 & 5 \\
\hline 562 & Machinist & 4 & 2 & 3 & 3 & 3 & 5 \\
\hline 563 & Refinisher Tech. & 4 & 2 & 3 & 3 & 3 & 5 \\
\hline 571 & Weapons Tech. (Air) & 4 & 2 & 3 & 2 & 2 & 5 \\
\hline 572 & Air Weapons Systems Tech. & 4 & 2 & 3 & 2 & 2 & 5 \\
\hline 611 & Construction Engineering Tech. & 4 & 3 & 3 & 3 & 3 & 5 \\
\hline 612 & Structures Tech. & 4 & 3 & 3 & 3 & 2 & 5 \\
\hline 613 & Plumber Gas Fitter & 4 & 3 & 3 & 3 & 2 & 5 \\
\hline 614 & Electrician & 4 & 2 & 3 & 3 & 2 & 5 \\
\hline 615 & Construction \& Maintenance Tech. & 4 & 3 & 3 & 3 & 3 & 5 \\
\hline 621 & Refrigeration \& Mechanical Tech. & 4 & 3 & 3 & 3 & 2 & 5 \\
\hline 622 & Electrical Generating Systems Tech. & 4 & 2 & 3 & 3 & 2 & 5 \\
\hline 623 & Stationary Engineer & 4 & 3 & 3 & 3 & 2 & 5 \\
\hline
\end{tabular}




\begin{tabular}{|c|c|c|c|c|c|c|c|}
\hline & OFFICERS & & & & & & \\
\hline $\begin{array}{l}\text { OCC. } \\
\text { CODE }\end{array}$ & OCCUPATION & V & $\mathrm{CV}$ & $\mathrm{H}$ & G & $\mathrm{O}$ & A \\
\hline 624 & Water, Sanitation and POL Tech. & 4 & 3 & 3 & 3 & 2 & 5 \\
\hline 625 & Mechanical Systems Tech. & 4 & 3 & 3 & 3 & 3 & 5 \\
\hline 631 & $\begin{array}{l}\text { Construction Engineering Procedures } \\
\text { Tech. }\end{array}$ & 4 & 3 & 3 & 3 & 3 & 5 \\
\hline 651 & Fire Fighter & 3 & 2 & 3 & 2 & 2 & 5 \\
\hline 711 & Medical Assistant & 4 & 3 & 3 & 2 & 2 & 5 \\
\hline 713 & Operating Room Assistant & 3 & 3 & 3 & 3 & 3 & 5 \\
\hline 714 & Laboratory Tech. & 4 & 2 & 3 & 3 & 3 & 5 \\
\hline 715 & X-Ray Tech. & 4 & 3 & 3 & 3 & 3 & 5 \\
\hline 716 & Preventative Medicine Tech. & 4 & 2 & 3 & 3 & 3 & 5 \\
\hline 717 & Aeromedical Tech. & 3 & 2 & 2 & 2 & 2 & 4 \\
\hline 722 & Dental Clinical Assistant & 4 & 3 & 3 & 3 & 3 & 5 \\
\hline 723 & Dental Laboratory Tech. & 4 & 3 & 3 & 3 & 3 & 5 \\
\hline 724 & Dental Equipment Tech. & 4 & 2 & 3 & 3 & 3 & 5 \\
\hline 725 & Dental Hygienist & 4 & 3 & 3 & 3 & 3 & 5 \\
\hline 811 & Military Police & 3 & 2 & 3 & 3 & 2 & 5 \\
\hline 831 & Administrative Clerk & 4 & 3 & 3 & 3 & 3 & 5 \\
\hline 841 & Finance Clerk & 4 & 3 & 3 & 3 & 3 & 5 \\
\hline 851 & $\begin{array}{l}\text { Physical Education and Recreation } \\
\text { Instructor }\end{array}$ & 4 & 3 & 3 & 2 & 2 & 5 \\
\hline 861 & Cook & 4 & 3 & 3 & 3 & 3 & 5 \\
\hline 862 & Steward & 4 & 3 & 3 & 3 & 3 & 5 \\
\hline 871 & Musician & 4 & 3 & 3 & 3 & 3 & 5 \\
\hline 881 & Postal Clerk & 4 & 3 & 3 & 3 & 2 & 5 \\
\hline 911 & Supply Tech. & 4 & 3 & 3 & 3 & 2 & 5 \\
\hline 921 & Ammunition Tech. & 4 & 1 & 3 & 2 & 2 & 5 \\
\hline
\end{tabular}




\begin{tabular}{||l|l|l|l|l|l|l|l||}
\hline \hline & \multicolumn{1}{|c|}{ OFFICERS } & & & & & & \\
\hline $\begin{array}{l}\text { OCC. } \\
\text { CODE }\end{array}$ & OCCUPATION & V & CV & H & G & O & A \\
\hline \hline 933 & Traffic Tech. & 3 & 2 & 3 & 2 & 2 & 5 \\
\hline 935 & Mobile Support Equipment Operator & 3 & 2 & 3 & 3 & 2 & 5 \\
\hline
\end{tabular}

\section{ANNEX B: CANADIAN FORCES PERSONNEL IN THE PERSIAN GULF}

\begin{tabular}{|c|c|c|}
\hline & OFFICERS & \\
\hline $\begin{array}{l}\text { OCCUPATION } \\
\text { CODE }\end{array}$ & OCCUPATION & $\begin{array}{l}\text { NUMBER OF } \\
\text { PERSONNEL }\end{array}$ \\
\hline 11 & General Officer & 1 \\
\hline 22 & Artillery & 1 \\
\hline 23 & Infantry & 14 \\
\hline 31 & Air Navigator & 5 \\
\hline 32 & Pilot & 61 \\
\hline 41 & Aeronautical Engineer & 5 \\
\hline 42 & $\begin{array}{l}\text { Communications and } \\
\text { Electronics Engineer }\end{array}$ & 9 \\
\hline 43 & $\begin{array}{l}\text { Land Engineering } \\
\text { Maintenance }\end{array}$ & 2 \\
\hline 44 & Maritime Engineer & 21 \\
\hline 51 & Dentist & 1 \\
\hline 54 & Pharmacist & 3 \\
\hline 55 & Medical (Doctor) & 34 \\
\hline 56 & Medical Associate & 6 \\
\hline 57 & Nurse & 52 \\
\hline 58 & Social Work & 1 \\
\hline 61 & Chaplain Protestant & 4 \\
\hline 62 & Chaplain Roman Catholic & 2 \\
\hline
\end{tabular}




\begin{tabular}{|c|c|c|}
\hline & OFFICERS & \\
\hline $\begin{array}{l}\text { OCCUPATION } \\
\text { CODE }\end{array}$ & OCCUPATION & $\begin{array}{l}\text { NUMBER OF } \\
\text { PERSONNEL }\end{array}$ \\
\hline 63 & Air Traffic Control & 1 \\
\hline 64 & Air Weapons Control & 2 \\
\hline 66 & Public Affairs & 7 \\
\hline 67 & Legal & 3 \\
\hline 68 & Personnel Administration & 2 \\
\hline 69 & Logistics & 21 \\
\hline 71 & Maritime Surface & 76 \\
\hline 81 & Security & 1 \\
\hline 82 & Intelligence & 10 \\
\hline \multirow[t]{2}{*}{ TOTAL } & & 345 \\
\hline & $\begin{array}{l}\text { NON-COMMISSIONED } \\
\text { MEMBERS }\end{array}$ & \\
\hline CODE & OCCUPATION & $\begin{array}{l}\text { NUMBER OF } \\
\text { PERSONNEL }\end{array}$ \\
\hline 011 & Crewman & 2 \\
\hline 021 & Artilleryman Field & 2 \\
\hline 022 & Artilleryman Air Defence & 25 \\
\hline 031 & Infantryman & 256 \\
\hline 041 & Field Engineer & 2 \\
\hline 042 & $\begin{array}{l}\text { Field Engineer Equipment } \\
\text { Operator }\end{array}$ & 1 \\
\hline 052 & Lineman & 4 \\
\hline 065 & Naval Weapons Tech. & 82 \\
\hline 081 & $\begin{array}{l}\text { Airborne Electronic Sensor } \\
\text { Operator }\end{array}$ & 2 \\
\hline 091 & Flight Engineer & 2 \\
\hline 111 & Intelligence Operator & 24 \\
\hline
\end{tabular}




\begin{tabular}{|c|c|c|}
\hline & OFFICERS & \\
\hline $\begin{array}{l}\text { OCCUPATION } \\
\text { CODE }\end{array}$ & OCCUPATION & $\begin{array}{l}\text { NUMBER OF } \\
\text { PERSONNEL }\end{array}$ \\
\hline 121 & Meteorological Tech. & 5 \\
\hline 171 & Air Defence Tech. & 9 \\
\hline 181 & Boatswain & 89 \\
\hline 211 & Radio Operator & 60 \\
\hline 212 & Teletype Operator & 13 \\
\hline 221 & Radio Tech. & 10 \\
\hline 222 & Terminal Equipment Tech. & 3 \\
\hline 223 & Teletype \& Cypher Tech. & 5 \\
\hline 224 & Communications Tech. & 1 \\
\hline 262 & Naval Signalman & 47 \\
\hline 273 & Naval Acoustics Operator & 24 \\
\hline 274 & Naval Radio Operator & 36 \\
\hline 275 & $\begin{array}{l}\text { Naval Combat Information } \\
\text { Operator }\end{array}$ & 61 \\
\hline 276 & $\begin{array}{l}\text { Naval Electronic Sensor } \\
\text { Operator }\end{array}$ & 54 \\
\hline 283 & $\begin{array}{l}\text { Naval Electronic Tech. } \\
\text { (Acoustics) }\end{array}$ & 12 \\
\hline 284 & $\begin{array}{l}\text { Naval Electronics Tech. } \\
\text { (Communications }\end{array}$ & 23 \\
\hline 285 & $\begin{array}{l}\text { Naval Electronics Tech. } \\
\text { (Tactical) }\end{array}$ & 40 \\
\hline 286 & $\begin{array}{l}\text { Naval Electronics Tech. } \\
\text { (Systems) }\end{array}$ & 9 \\
\hline 291 & Communications Research & 14 \\
\hline 312 & Marine Engineering Mechanic & 53 \\
\hline 313 & Marine Engineering Tech. & 69 \\
\hline 314 & Marine Engineering Artificer & 27 \\
\hline
\end{tabular}




\begin{tabular}{|c|c|c|}
\hline & OFFICERS & \\
\hline $\begin{array}{l}\text { OCCUPATION } \\
\text { CODE }\end{array}$ & OCCUPATION & $\begin{array}{l}\text { NUMBER OF } \\
\text { PERSONNEL }\end{array}$ \\
\hline 321 & Hull Tech. & 48 \\
\hline 331 & Electrical Tech. & 31 \\
\hline 331 & Marine Electrician & 24 \\
\hline 342 & Clearance Diver Tech. & 7 \\
\hline 411 & Vehicle Tech. & 30 \\
\hline 421 & Weapons Tech. Land & 4 \\
\hline 432 & $\begin{array}{l}\text { Fire Control Tech. } \\
\text { (Electronic) }\end{array}$ & 8 \\
\hline 433 & Fire Control Tech. (Optronic) & 3 \\
\hline 435 & $\begin{array}{l}\text { Fire Control System Tech. } \\
\text { (Land) }\end{array}$ & 2 \\
\hline 441 & Materials Tech. & 2 \\
\hline 511 & Aeroengine Tech. & 31 \\
\hline 512 & Air Frame Tech. & 41 \\
\hline 513 & Aviation Tech. & 5 \\
\hline 521 & Integral Systems Tech. & 25 \\
\hline 524 & $\begin{array}{l}\text { Communications and Radar } \\
\text { Systems Tech. }\end{array}$ & 29 \\
\hline 525 & Avionics Tech. & 4 \\
\hline 531 & Safety Systems Tech. & 17 \\
\hline 541 & Photographic Tech. & 5 \\
\hline 551 & Instrument Electrical Tech. & 20 \\
\hline 561 & Metals Tech. & 6 \\
\hline 562 & Machinist & 2 \\
\hline 563 & Refinisher Tech. & 5 \\
\hline 571 & Weapons Tech. (Air) & 93 \\
\hline
\end{tabular}




\begin{tabular}{|c|c|c|}
\hline & OFFICERS & \\
\hline $\begin{array}{l}\text { OCCUPATION } \\
\text { CODE }\end{array}$ & OCCUPATION & $\begin{array}{l}\text { NUMBER OF } \\
\text { PERSONNEL }\end{array}$ \\
\hline 612 & Structures Tech. & 3 \\
\hline 614 & Electrician & 3 \\
\hline 621 & $\begin{array}{l}\text { Refrigeration and Mechanical } \\
\text { Tech. }\end{array}$ & 3 \\
\hline 622 & $\begin{array}{l}\text { Electrical Generating Systems } \\
\text { Tech. }\end{array}$ & 7 \\
\hline 624 & $\begin{array}{l}\text { Water, Sanitation and POL } \\
\text { Tech. }\end{array}$ & 4 \\
\hline 631 & $\begin{array}{l}\text { Construction Eng. Procedures } \\
\text { Tech. }\end{array}$ & 1 \\
\hline 651 & Firefighter & 19 \\
\hline 711 & Medical Assistant & 100 \\
\hline 713 & Operating Room Assistant & 12 \\
\hline 714 & Medical Laboratory Tech. & 4 \\
\hline 715 & X-Ray Tech. & 4 \\
\hline 716 & Preventive Medicine Tech. & 3 \\
\hline 717 & Aeromedical Tech. & 1 \\
\hline 811 & Dental Clinical Assistant & 2 \\
\hline 811 & Military Police & 17 \\
\hline 831 & Administration Clerk & 52 \\
\hline 841 & Finance Clerk & 12 \\
\hline 851 & $\begin{array}{l}\text { Physical Education and } \\
\text { Recreation Instructor }\end{array}$ & 1 \\
\hline 861 & Cook & 59 \\
\hline 862 & Steward & 40 \\
\hline 881 & Postal Clerk & 8 \\
\hline 911 & Supply Tech. & 87 \\
\hline
\end{tabular}




\begin{tabular}{||l|l|l||}
\hline & \multicolumn{1}{|c|}{ OFFICERS } & \\
\hline $\begin{array}{l}\text { OCCUPATION } \\
\text { CODE }\end{array}$ & OCCUPATION & $\begin{array}{l}\text { NUMBER OF } \\
\text { PERSONNEL }\end{array}$ \\
\hline \hline 921 & Traffic Tech. & 7 \\
\hline 935 & $\begin{array}{l}\text { Mobile Support Equipment } \\
\text { Operator }\end{array}$ & 54 \\
\hline TOTAL & & 2,018 \\
\hline
\end{tabular}

\section{ANNEX C: TABLE OF ACRONYMS}

$\begin{array}{ll}\text { BFOQ } & \text { - Bona Fide Occupational Qualification } \\ \text { BFOR } & \text { - Bona Fide Occupational Requirement } \\ \text { CAF } & \text { - Canadian Armed Forces } \\ \text { CEP Tech. } & \text { - Construction Engineering Procedures Technician } \\ \text { CF } & \text { - Canadian Forces } \\ \text { CFAO } & \text { - Canadian Forces Administrative Order } \\ \text { CFB } & \text { - Canadian Forces Base } \\ \text { CMES } & \text { - Common Minimum Enrolment Standard } \\ \text { CMRB } & \text { - Career Medical Review Board } \\ \text { CWO } & \text { - Chief Warrant Officer } \\ \text { DND } & \text { - Department of National Defence } \\ \text { GMD } & \text { - General Military Duty(ies) } \\ \text { GSNCM } & \text { - General Specification for non-commissioned members } \\ \text { NDHQ } & \text { - National Defence Headquarters } \\ \text { NCM } & \text { - Non-commissioned members } \\ \text { POL } & \text { - Petroleum, Oil and Lubricants } \\ \text { Tech. } & \text { - Technician }\end{array}$

